$$
\begin{aligned}
& \text { UNIVERSIDADE DE SÃO PAULO } \\
& \text { INSTITUTO DE PSICOLOGIA }
\end{aligned}
$$

WILSON DE ALBUQUERQUE CAVALCANTI FRANCO

\title{
Autorização e angústia de influência em Winnicott
}




\section{WILSON DE ALBUQUERQUE CAVALCANTI FRANCO}

\section{Autorização e angústia de influência em Winnicott}

Dissertação apresentada ao Instituto de Psicologia da Universidade de São Paulo como parte dos requisitos para obtenção do grau de Mestre em Psicologia

Área de Concentração: Psicologia Experimental

Orientador: Luís Cláudio Figueiredo

São Paulo 
AUTORIZO A REPRODUÇÃO E DIVULGAÇÃO TOTAL OU PARCIAL DESTE TRABALHO, POR QUALQUER MEIO CONVENCIONAL OU ELETRÔNICO, PARA FINS DE ESTUDO E PESQUISA, DESDE QUE CITADA A FONTE.

Catalogação na publicação

Biblioteca Dante Moreira Leite

Instituto de Psicologia da Universidade de São Paulo

Franco, Wilson de Albuquerque Cavalcanti.

Autorização e angústia de influência em Winnicott / Wilson de Albuquerque Cavalcanti Franco; orientador Luís Cláudio Figueiredo. - São Paulo, 2012.

$84 \mathrm{f}$.

Dissertação (Mestrado - Programa de Pós-Graduação em Psicologia. Área de Concentração: Psicologia Experimental) Instituto de Psicologia da Universidade de São Paulo.

1. Psicanálise 2. História da psicologia 3. Winnicott, Donald Woods, 1896-1971 4. Autoria I. Título.

RC504 
NOME: Wilson de Albuquerque Cavalcanti Franco

TÍTULO: Autorização e angústia de influência em Winnicott

Dissertação apresentada ao Instituto de Psicologia da Universidade de São Paulo como parte dos requisitos para obtenção do grau de Mestre em Psicologia

Área de Concentração: Psicologia Experimental

Orientador: Luís Cláudio Figueiredo

Aprovado em:

Banca examinadora:

Prof. Dr:

Instituição:

Julgamento:

Assinatura:

Prof. Dr:

Instituição:

Julgamento:

Assinatura:

Prof. Dr.:

Instituição:

Julgamento:

Assinatura: 
A meus pais, todos eles, $e$ aos filhos que eu venha a ter. 


\section{AGRADECIMENTOS}

Nunca pensei que, quando chegasse o momento, eu pudesse agradecer devidamente a todos os envolvidos nesse meu processo, agradecer tudo o que fizeram. A hora chegou e a sensação ainda é a mesma. Tento, a seguir, mencionar um mínimo que seja da imensa contribuição de todos que me acompanham e auxiliam ao longo do caminho.

Acima de tudo, agradeço a Luís Cláudio a orientação imprescindível, incontornável, insuperável - como agradecer-lhe suficientemente? Obrigado, obrigado e obrigado.

Aos colegas do grupo de orientação, agradeço a companhia, a paciência e os conselhos

A Talita - ar que eu respiro, lar que me abriga, raiz que me sustenta: amor da minha vida.

A Patrícia e Marcelo, pontos de apoio e de referência nessa difícil profissão.

Aos meus amigos, que tornam a vida digna de ser vivida e celebrada, e que não me deixam esquecer-me de celebrá-la, relapso que sou. Um agradecimento particularmente especial a Rafael, meu irmão e companheiro de andanças pelo pensamento, e a Elisa, pela leitura e pelas sugestões ao longo da escrita.

Ao meu pai, à minha mãe e à minha irmã, sou grato pelo apoio, pela confiança e por verem em mim tudo o que ainda não sou, mas que quero e espero um dia poder ser. À minha família, no geral, por me dar lugar no mundo.

Aos colegas de trabalho em saúde mental, no CAPS Itapeva, no breve grupo de estudos e, mais recentemente, em Taboão da Serra.

Ao CNPq, agradeço o financiamento. 
Aquilo que herdaste de teus pais, adquire-o, para possuí-lo.

Wolfgang Von Goethe, Fausto 


\section{RESUMO}

FRANCO, Wilson de Albuquerque Cavalcanti. Autorização e angústia de influência em Winnicott. Dissertação (Mestrado) - Instituto de Psicologia, Universidade de São Paulo, São Paulo, 2012.

O presente trabalho tem como objetivo abordar a forma como se constelaram as angústias de influência para que Winnicott se tornasse o autor que conhecemos - em resumo, como se passou a autorização de Winnicott. Suponho que a obra escrita de um autor é a ponta visível de um processo que denominei autorização; a ideia é que todo autor lida, em alguma medida, com angústias associadas à significação que o escrever e/ou o ser-autor assumem para ele. Essa autorização conflui, do ponto de vista assumido aqui, com um reconhecimento e uma afirmação de si perante os pares e as figuras de autoridade que retomam, na chave do grupo de destino da escrita do autor, as questões que a criança tem na fase edípica; tal leitura remonta em muito ao tema da angústia de influência, trabalhada por Harold Bloom, e ao testemunho que Ronald Britton oferece da mesma problemática em relação ao meio psicanalítico. No caso singular de Winnicott, considero o processo de autorização como estando muito relacionado à busca por autenticidade; esta, por sua vez, é entendida como associada ao próprio reconhecimento da existência e da legitimação das formas singulares de afirmação do autor. À sua maneira, Winnicott parece colocar em novos termos a questão em torno da autoridade, na medida em que subverte a problemática da submissão a uma lei maior que funcionaria como tabu - a questão passaria por criar uma via própria, singular, por equacionar os imperativos estabelecidos, mas, nesse mesmo gesto de reconhecimento, ele incute uma inovação. A formulação final a que chego, tendo em vista esses aspectos, é que a liberdade de leitura ou a incorporação criativa da tradição ocupam em Winnicott o lugar que a infelicidade cotidiana ou a aceitação da castração assumem em Harold Bloom; na autorização winnicottiana, a liberdade e a idiossincrasia parecem ocupar o lugar que, na triangulação edípica, compete ao pai - formulação certamente paradoxal, mas que busca fazer justiça ao pensamento do autor.

Palavras-chave: psicanálise; história da psicologia; Winnicott, Donald Woods; autoria. 


\begin{abstract}
FRANCO, Wilson de Albuquerque Cavalcanti. Authorization and the anxieties of influence in Winnicott. Master's dissertation. University of São Paulo, São Paulo, 2012.

This work aims to discuss how influence anxieties constellate in the manner through which Winnicott became the author we know, and how we know him (or it) - in brief, how Winnicott authorization proceeded. We believe the written oeuvre of an author is the distinguishable tip of the process we named "authorization"; we understand an author deals, somehow, which anxieties connected to the signification what writing and/or being an author assume to him. This authorization surmounts the process of recognition and self-standing among peers and authority figures, and bring forth in the process of writing for an audience the issues the child undertakes through its oedipical phase; this understanding owes much to the discussions on the anxiety of influence, established around Harold Bloom's publications, and to the "testimony" granted by Ronald Britton about the same topic in regard to his own experience in the psychoanalytical field. In Winnicott's case we alleged the authorization process is profoundly related to his search for authenticity, and authenticity, in its turn, has been associated with the recognition of existence and of singular means of existence. In his terms Winnicott seems to have subverted the problematic around the submission to a higher law established as a taboo - the problem would be subverted into being that of the search and creation of a particular and singular path equating the manners involved; in that very constitution of the problem the subversion of the classical portrayal of the authorization amidst established and unquestionable authorities, a paradoxical revolution insinuates itself. We claim lastly that in Winnicott's work the "freedom of thought" and the "creative incorporation of tradition" occupy the place that formerly the "everyday misery" and the acceptance of castration assumed, e.g. in Harold Bloom's work. In Winnicott's authorization process freedom and idiosyncrasy occupy the place that, in the classical oedipical triangulation, the father occupies - formulation undoubtedly paradoxical, but apparently appropriate to the author's theory.
\end{abstract}

Keywords: psychoanalysis; history of psychology; Winnicott, Donald Woods; authorship. 


\section{SUMÁRIO}

INTRODUÇÃO 9

JUSTIFICATIVA 10

TRADIÇÃO NO TEMA 14

PARTE I - APROPRIAÇÃO 19

CAPÍTULO 1 - APRESENTAÇÃO OPERACIONAL DE CONCEITOS-CHAVE 20

AUTOR E OBRA 20 INFLUÊNCIA 23

CAPÍTULO 2 - DÍVIDA E INFLUÊNCIA NO PENSAMENTO PSICANALÍTICO 28 DEVEMOS TUDO A FREUD 28 A CASA DA MOEDA PSICANALÍTICA 30

NÃO-VIOLÊNCIA E FURTO 32 EXCÊNTRICO E IMAGINATIVO 34

PARTE II - POSSE 37

CAPÍTULO 3 - UM LUGAR À SOMBRA, UM LUGAR AO SOL 38

APRESENTAÇÃO 38

OS OUTROS EM MIM 39

O MESTRE E A MADONA 42

UMA MATRIZ DE RELACIONAMENTOS DEFENSIVOS 45

UMA MOLDURA PARA OS RELACIONAMENTOS 49

CAPÍTULO 4 - AUTORIZAÇÃO E AUTENTICIDADE 54

VERDADES INCOMUNICÁVEIS 54

O ESTATUTO DOS LÍDERES E DOS SEGUIDORES 59

A FÁBULA DO AUTOR 62

O FILHO TARDIO 67

CONSIDERAÇÕES FINAIS 71

O LEITOR QUE FECHA O LIVRO 72

PEDRA SOBRE PEDRA 74

O AUTOR QUE FECHA O LIVRO 79 


\section{INTRODUÇÃO}




\section{JUSTIFICATIVA}

A expressão "angústia de influência" foi tratada como conceito pela primeira vez por um crítico literário, Harold Bloom. Bloom afirma que os autores situam seus trabalhos em interlocução com os autores já estabelecidos no campo e que essa relação acaba se configurando inevitavelmente como uma relação de autoridade: o autor já estabelecido agindo sobre o autor em processo (BLOOM, [1973] 2002).

A perspectiva apresentada por Bloom influenciou outros campos, dentre eles a psicanálise. Ronald Britton, dois anos após a publicação do primeiro livro de Bloom a esse respeito, afirmou que todo autor psicanalítico tem de lidar com esse tipo de angústia (que ele acabou por nomear, em vista de seus interesses específicos, como ansiedade de publicação); para Britton, a questão está na forma como o processo se desencadeia em cada autor e nas implicações dessa ansiedade para a clareza da argumentação no texto. Analisando as republicações de um texto escrito por ele próprio, Britton percebe que, nas primeiras publicações, esteve muito ocupado com as angústias relativas à sua própria constelação de influências, de modo que essas angústias tornaram seu texto confuso ou mesmo impreciso (BRITTON, 2003).

Além de si mesmo, Britton estudou a forma como as ansiedades ligadas à publicação e à autorização influenciaram o trabalho de Charles Darwin e de Donald Winnicott, nosso principal interesse aqui. Britton, na verdade, não foi o único a abordar as ansiedades de influência em Winnicott: depois dele, a mesma questão foi retomada por Adam Phillips, Thomas Ogden e Luís Cláudio Figueiredo (PHILLIPS, [1988] 2007; OGDEN, [2001] 2002; FIGUEIREDO, 2002). Em seu trabalho, Britton havia abordado a forma como Winnicott procurava diálogo e aceitação de seus argumentos junto a Melanie Klein e Anna Freud como indicativo de que ele sofria com as ansiedades ligadas à autorização, autorização que procurava junto a figuras de autoridade para ele, nas cartas que escrevia. Ogden e Phillips foram mais longe, apontando passagens da obra de Winnicott em que ele se mostra confuso e impreciso. Para esses autores, Winnicott, que no geral era um escritor claro e consistente, escrevia de forma oblíqua e imprecisa justamente nos momentos em que trazia inovações (ou rupturas) significativas em face da tradição psicanalítica.

Uma leitura mais atenta permite verificar vários momentos em que o próprio Winnicott fala sobre sua dificuldade em afirmar-se perante a autoridade estabelecida; em uma clássica passagem, ele diz que não consegue estabelecer seu argumento a partir das teorias de 
outras pessoas (estabelecidas na tradição), porque sua mente não funciona dessa maneira (WINNICOTT, [1945] 2000a, p. 218). Em geral, essa afirmação é vista como uma escolha, e estou sugerindo que ela talvez não o seja: talvez a mente dele "não funciona" assim como a mente de alguém "não funciona" se estiver em um contexto que inviabilize o pensamento - o motorista entra em greve e a máquina não anda, "não funciona" dessa maneira.

Concordo com Britton quando ele afirma que todo autor sofre, em alguma medida, de angústia de influência; não creio que se trate de um traço caracteriológico ou de um diagnóstico patológico a recair sobre autores "fracos" ou doentes. Creio, todavia, que a angústia de influência determina o processo de autorização por meio do qual a pessoa consegue (ou não) se afirmar como autor - a angústia determina se a pessoa consegue ou não, além de também determinar o modo como isso se dá. Acho que há um processo de autorização subjacente - e particular - a cada autor. Britton escreveu sobre a forma como a influência se manifestou em seus próprios escritos; Freud disse que evitava ler Schopenhauer e Nietzsche pela influência que poderiam ter em seus pensamentos; Bloom cita outros tantos autores que recusam ou se prostram diante dos autores que os influenciam. Winnicott tinha suas próprias angústias, suas próprias influências, e se autorizou de forma notável, tanto pelas resistências que enfrentou quanto pelas marcas que o processo de autorização imprimiu em seu pensamento.

Creio que o "caso" de Winnicott seja digno de estudo no campo da influência e da autorização em psicanálise por uma série de razões, dentre as quais destaco quatro:

1. porque ele escreveu no meio psicanalítico, em que há monstros que efetivamente povoam o mar;

2. porque ele escreveu em um período difícil do ponto de vista da autoria, quando se disputavam os escolhos do "pai totêmico" Freud, falecido havia pouco tempo;

3. porque ele abordou a questão do legado e da dívida simbólica de forma inovadora na psicanálise;

4. porque seu trabalho suscitou um amplo debate sobre seu pertencimento ou não à psicanálise e sobre a natureza de sua posição relativamente a Freud e Klein sua iconoclastia, sua idolatria.

O primeiro item é pessoalmente significativo para mim. Se as angústias de influência e autorização são um fenômeno presente em cada candidato a autor, no meio psicanalítico esse 
percurso parece particularmente difícil, na medida em que impõe ao iniciante relações de autoridade e prioridade em diversos níveis: com o analista pessoal, com o supervisor, com os autores de maior ascendência sobre o pensamento do novato, com Freud. Ademais, se em qualquer publicação existe a necessidade de lidar com a pressão dos pares (peer pressure), no caso da psicanálise essa pressão parece aumentada pela tensão entre a publicação e o conteúdo altamente particular e íntimo do material com que a psicanálise lida; mesmo para os mais ciosos e tranquilos, a publicação em psicanálise parece ser indelevelmente matéria delicada; soma-se a isso o jogo de poder e vaidade que tantas vezes se estabelece na comunidade psicanalítica, regional e temporalmente. Por tudo isso, creio ser necessário considerar os efeitos da instituição psicanalítica sobre a autorização; espero aqui poder contribuir para essa discussão, que mobilizo pelo viés histórico do "caso" Winnicott, mas que pretendo válida para a questão em seu caráter contemporâneo.

Relativamente ao segundo item, tenho em vista o contexto da Sociedade Britânica de Psicanálise e a conjuntura geral em que Winnicott trabalhava. Winnicott entrou para a instituição psicanalítica no momento em que se desdobravam as "controvérsias" entre Melanie Klein e Anna Freud (e seguidores de ambas as partes) no que acabou se configurando como uma verdadeira Guerra Fria dentro da Sociedade (Hélio Pellegrino bem observou que as microinstituições refletem em escala lilliputtiana "as vicissitudes estruturais e as mazelas das macroinstituições"; KUPERMANN, 2008, p. 44). Essa configuração de forças desagradava a Winnicott sobremaneira, e a prova disso são as inúmeras cartas e trabalhos em que ele tenta mostrar a necessidade de as filiações dogmáticas serem deixadas de lado em prol de um ambiente de amplo debate e necessária frustração, ao cabo do qual - cria ele - haveria de se evidenciar a maior precisão de alguns aspectos em detrimento de outros, com a vitória da ciência e da sociedade sobre as igrejas e os clubinhos (WINNICOTT, [1987] 2005). Winnicott parece ter conseguido pôr em perspectiva a filiação à tradição no pensamento psicanalítico, mantendo-a em alta conta ao mesmo tempo em que sugeriu possibilidades de pensamento criativo e inovação, ou seja: mantendo o respeito à tradição e a Freud, Winnicott foi decisivo ao sugerir que os psicanalistas poderiam "seguir em frente" com a psicanálise e com suas vidas. Isso parece ter sido particularmente importante na Inglaterra em vista do estabelecimento da família Freud por lá, com o que inevitavelmente acabou se instalando também lá o litígio sobre a herança: Anna Freud como "detentora da insígnia” e representante da legitimidade, Melanie Klein como representante do "espírito inovador" e da fidelidade aos princípios do empreendimento psicanalítico; essa disputa certamente poderia ter arruinado a 
"família" psicanalítica, no mínimo dentro da Inglaterra, não fosse sua dissolução não-violenta através da instituição do Middle Group e dos “panos quentes” sobre a questão.

O terceiro item só se apresentou a mim a partir dos desdobramentos das leituras e ao longo da pesquisa; talvez ele seja, por isso, um resultado da pesquisa. O ponto aqui é que na psicanálise de inspiração kleiniana (por exemplo, em SEGAL, [1955] 1969), na teorização do processo criativo em Harold Bloom ([1973] 2002) e mesmo em alguns textos de Freud (exemplarmente no texto sobre da Vinci; FREUD, [1910] 1973b), a criação artística se encontra vinculada ao sintoma e às tentativas de "resolução" das frustrações. No caso de Winnicott, no entanto, há uma teorização mais "livre" para o processo criativo, teorização que não se centra sobre a dívida ao pai e à castração e que postula o processo criativo como expressão do self verdadeiro, a partir da criação de um ambiente acolhedor e nutriente (como abordado, por exemplo, em Creativity and its origins; WINNICOTT, [1971] 2010).

Quanto ao último item, tenho como origem desta pesquisa justamente esta problematização: qual é o lugar de Winnicott perante a psicanálise? Há uma tradição de leitura, sediada em São Paulo, que tende a compreender Winnicott como alguém que "superou" a psicanálise (LOPARIC, 1996) - e a tentativa de compreender essa leitura (pressupondo que não concordava com ela, mas tentando entender por que conseguiu tanta repercussão) contribuiu em muito para que o trabalho chegasse até aqui. A forma peculiar com que Winnicott lidava com a tradição e sua postura desrespeitosa à "lei de talião" da influência (na linha "roubo o que penso e não pago a quem devo" WINNICOTT, [1945] 2000a) certamente devem ser observadas mais de perto, justamente para que se desfaça a sorte de mal entendido que leva os mais afoitos a entendê-lo como "profeta" ou como autor "fora de escolas". Apesar de suas tendências iconoclastas (como ele refere-se a si mesmo em carta a Anna Freud e Melanie Klein), Winnicott estava muito mais propenso a "atuar" como Jesus Cristo (sacrificando-se, incompreendido, em nome da Verdade do Pai) do que como profeta (revelador da Boa Nova de que se faz representante e porta-voz; RODMAN, 2003). De minha parte, não ponho em questão se Winnicott é ou não psicanalista, e não considero a psicanálise uma ciência organizada em torno de paradigmas à la Kuhn.

Acima dessas e organizando as quatro justificativas que apresentei, acredito que a origem primeira da pesquisa é muito mais pontual: por que Winnicott escrevia como escrevia? Esta é provavelmente a colocação mais sucinta e honesta para a pergunta que mobiliza a presente pesquisa; esta é minha pedra de tropeço. Cheguei a esta pergunta por estranhar a afirmação muitas vezes repetida de que o texto de Winnicott parece simples, mas não é, e de 
que é necessária uma leitura atenta para descobrir (ou criar) os elementos que estão em jogo em cada frase. A partir daí comecei a pensar que o texto de Winnicott era um "falso texto simples", e por isso acabava sendo um texto duplamente difícil: difícil porque é complexo e difícil porque é difícil perceber que ele é difícil. Até hoje não consigo formular esta questão ao seu limite, onde ela se desmancha por estar respondida/ exaurida - e creio estar satisfeito com isso.

\section{TRADIÇÃO NO TEMA}

O campo geral em que se insere esta pesquisa é a psicanálise. Trata-se de um trabalho sobre a história da psicanálise, na medida em que estuda o contexto de instauração da obra de um autor; é também um trabalho sobre o campo winnicottiano, na medida em que toma a constituição desse campo em causa; e na medida em que se preocupa com as destinações contemporâneas da obra desse autor, é também uma pesquisa sobre a instituição psicanalítica ${ }^{1}$.

Construo este trabalho na interface entre dois campos relativamente independentes de estudos na psicanálise: por um lado, tenho em vista a obra winnicottiana, como conjunto de textos escrito por Winnicott e como conjunto (maior) de textos psicanalíticos que encontram em Winnicott fundamento e legitimidade; por outro, tenho em vista a problemática da autoria e da influência no delineamento da escritura de um autor singular, campo que pertence, ao menos em origem, à crítica literária. O cruzamento desses dois campos incide sobre um "terceiro" campo, campo da sobreposição dos dois já citados, largamente influenciado por campos como a historiografia psicanalítica erudita, a pesquisa sobre psicanálise, sobre o dispositivo psicanalítico, a instituição psicanalítica.

Do ponto de vista da vasta bibliografia a respeito da vida e da obra de Winnicott, creio ser importante ressaltar que tomo como problemas a influência e o processo de autorização, problemas adjacentes a alguns outros, mas distintos deles. Posiciono-me em meio àqueles que pude ler, bagagem certamente insatisfatória em face da vastidão da bibliografia mundialmente acumulada em torno dos temas.

Há estudos, por exemplo, sobre a forma como Freud e Melanie Klein influenciam a teorização de Winnicott. Roberto Graña (2007), Tales Ab’Sáber (1997), Luís Cláudio

\footnotetext{
1 Não tenho condições de me demorar em considerações sobre as questões próprias à pesquisa em psicanálise e meu posicionamento perante esse ponto. Estou de acordo com os argumentos formulados a esse respeito por Inês Loureiro (2002) em texto dedicado ao tema, ao qual remeto o leitor interessado no assunto.
} 
Figueiredo (2002) e José Outeiral (OUTEIRAL e CELERI, 2002) são alguns dos que trabalham nesse sentido. Seus trabalhos são representativos de um esforço coletivo para pôr a obra de Winnicott em diálogo com os demais autores em psicanálise, tarefa imprescindível já que o próprio Winnicott tinha clara dificuldade em fazê-lo. O trabalho desses autores é particularmente difícil e meritório, já que eles têm de enxergar conexões "abaixo" do texto, como se fizessem um diagnóstico da infraestrutura textual - a infraestrutura psicanalítica em que Winnicott se fundava ao desenvolver sua teoria. Não me deterei aqui sobre as condições de infraestrutura do pensamento de Winnicott, mas meu trabalho depende do trabalho desses autores na medida em que estudo a forma como a ansiedade de influência aparece na obra de Winnicott, o que fica bastante facilitado pelo esclarecimento que eles favorecem quanto à relação das ideias de Winnicott com seus "influentes"2.

Outros autores buscam pôr Winnicott em interlocução com a ambientação intelectual de nosso tempo, como no livro organizado por Benilton Bezerra Junior e Francisco Ortega (2007), ou mesmo no trabalho de Roberto Graña (2007) já citado aqui - a primeira parte de seu texto associa Winnicott a outros autores da psicanálise, ao passo que a segunda o associa a filósofos modernos e contemporâneos. São trabalhos interessantes e estimulantes, mas que fogem ao meu objetivo na leitura que aqui proponho para o trabalho de Winnicott.

Há outra série crescente de estudos que buscam "aprofundar" os textos de Winnicott, criando associações, comunicações, relações; esses autores se baseiam na preocupação com o estilo coloquial e alusivo de Winnicott e, ao mesmo tempo em que elogiam seus méritos, tentam "reduzir os danos" dessas escolhas com uma espécie de aprofundamento ou ancoragem do texto. Bons exemplos desse tipo de trabalho são os "dicionários" do pensamento de Winnicott elaborados por Jan Abram (1996) e Alexander Newman (1995). Em linha semelhante, mas paralela, há os trabalhos de cunho mais biografista em que os trabalhos de Winnicott são distribuídos em séries e associados ao contexto de sua criação e aos momentos de vida do "homem que escreveu os textos". Nesse sentido, o livro que estabelece mais claramente um argumento é o de Adam Phillips ([1988] 2007); as biografias propostas por Brett Kahr (1996) e por Robert Rodman (2003), principalmente a escrita por esse último, são mais influenciadas pela tradição literária biográfica clássica. Um pouco "fora da curva", mas ainda nessa tradição, está o livro das tradutoras de Winnicott para o francês, Anne

\footnotetext{
2 Chamou-me a atenção, ao longo das pesquisas de bibliografia e estado da arte, a ausência de trabalhos especificamente voltados à influência de James Strachey sobre Winnicott; falta-me recurso e erudição para tratar do tema, que apesar disso me parece (intuitivamente, já que não disponho de evidências) tocar uma questão digna de nota.
} 
Clancier e Jeannine Kalmanovitch ([1984] 1987), e alguns dos textos de Jean-Bertrand Pontalis ([1977] 2005) que compõem seu antológico Entre o sonho e a dor. Há um mérito claro nesses livros, que é o adensamento e a sistematização de um pensamento exposto de forma bastante peculiar em vista da tradição moderna ocidental, mas alguns desses trabalhos acabam "sabotando" de alguma forma o mecanismo proposto por Winnicott através da escolha de seu estilo, que é a imposição do desafio de habitar o texto até compreendê-lo, com o que a compreensão se efetiva de forma singular e pessoal. Suponho que esses trabalhos, por mais cuidadosos que sejam, correm o risco de convidar a certa ortodoxia winnicottiana - que é nada mais nada menos que a dispensação, por parte do leitor, do exercício do pensamento, "comprando fiado" esse pensamento de um autor que já teria feito isso pelo leitor. Talvez fosse um risco inevitável, no entanto, e os trabalhos nessa linha que pude ler são conduzidos de forma cuidadosa e comprometida. No Brasil, o trabalho mais significativo que li a esse respeito foi a dissertação de mestrado de Téo Weingrill Araújo (2005), Tradição e Originalidade na Obra de Donald Winnicott. Araújo aborda o primeiro livro publicado por Winnicott, ainda ancorado plenamente na pediatria e nos primeiros momentos da análise pessoal com Strachey, encontrando já aí os elementos básicos do que viria a ser a plena contribuição winnicottiana décadas mais tarde. Apesar das diferenças de escolha metodológica e referencial, tenho o trabalho de Araújo em alta conta por sua precisão e por seu refinamento crítico.

Devo muito aos livros de Dodi Goldman (1993a, 1993b) a respeito do pensamento de Winnicott; parecem-me livros profundamente inspirados pelo estilo de Winnicott, fiéis a esse estilo e, no entanto, livres em relação a ele $^{3}$ - talvez um dos poucos casos de algo que possa ser considerado um bom winnicottismo, se é que isso é possível. Um dos aspectos que mais me impactou no trabalho de Goldman foi a apresentação de um Donald Winnicott complexo, ambíguo, com nuances e detalhes ausentes nas caricaturas e nos relatos mais consagrados, em que o psicanalista inglês é descrito quase como um bom vovô com traços clownescos; fiquei feliz ao encontrar, através do relato de Dodi Goldman e amparado por outros aspectos levantados por Robert Rodman (em sua biografia de Winnicott já mencionada ${ }^{4}$ ), a sombra de um homem, um homem genial, um homem difícil e peculiar, mas um homem - não um ídolo,

3 um pouco diferentes nesse aspecto, no entanto: In one's bones é nitidamente mais "livre" que In search of the real, talvez pelo próprio propósito dos livros.

${ }_{4} \quad$ Rodman expõe de forma clara elementos sobre a fantasia de homem por trás do autor Winnicott que não encontrei em outros autores com tendência hagiográfica: sua posição fragilizada e insegura diante das mulheres Alice Taylor e Clare Britton, a influência decisiva dessa última sobre sua possibilidade de autorizar-se e algumas lembranças de infância de Winnicott que claramente lançam luz sobre sua forma de afirmar-se. 
não um totem, não um mestre.

Preciso fazer notar ainda, mesmo que brevemente, a ambientação de meu trabalho no contexto da história e da teoria da psicanálise.

Incorporei ao texto as proposições de Daniel Kupermann a partir de seu livro Transferências cruzadas: uma história da psicanálise e suas instituições (KUPERMANN, 1996). O argumento de Kupermann é uma das fontes de inspiração deste trabalho; talvez seja possível dizer que aqui se trata de uma tentativa de "anexar" à exposição do autor as problematizações cabíveis a partir da presença de Winnicott na instituição psicanalítica, como membro "excêntrico e imaginativo" na melhor tradição da primeira geração de analistas e como autor inovador no contexto da teoria psicanalítica. O livro de Phyllis Grosskurth, $O$ círculo secreto (GROSSKURTH, 1992), funciona para mim como "bibliografia de base" para a fundação (como "obra") e aprofundamento (como ciência) do argumento de Kupermann ao longo de todo o texto, e mais notavelmente ao longo do capítulo 2, tive-o em mente, mesmo que não o explicite em citações e referências.

Secrets of the soul, de Eli Zaretsky (2005) serviu também de ambientação para meu trabalho, ainda que o calibre e o escopo de suas preocupações tornem sua obra muito mais um pano de fundo do que propriamente um interlocutor de meu texto. Os capítulos de seu livro em que ele se aproxima da problemática da Sociedade Britânica e do contexto de trabalho de Winnicott, no entanto, em muito me auxiliaram a localizar-me em meio aos textos e às problemáticas tantas vezes labirínticas.

São esses alguns dos problemas que "dividem muros" com o que abordo aqui, mas sobre os quais não pretendo me deter. Para o leitor interessado, indico os autores que citei.

Talvez deva adicionar ainda, tendo como tarefa para introduzir o leitor ao trabalho, uma ou outra nota breve sobre a minha transferência com a pesquisa como tema, filiação e estudo de autor. O mais honesto e breve seria dizer que não escolhi Winnicott, nem escolhi o tema deste trabalho: fui escolhido por eles. Nunca havia me disposto a destruir Winnicott, nem a idealizá-lo - ao longo dessa pesquisa, curiosamente e a despeito de mim mesmo, encontrei oportunidade para "me pegar" fazendo as duas coisas, separadamente ou ao mesmo tempo; nas páginas que seguem, apresento o Winnicott em mim que sobreviveu a isso tudo, associado a um pouco de bom senso acadêmico, e uma ou outra teorização oportuna.

Winnicott não foi objeto de transferência significativa para mim anteriormente à pesquisa e eu não havia, até então, detido-me em um estudo sistemático sobre a obra do autor; não considero que este trabalho seja winnicottiano nem que eu, como pesquisador ou mesmo 
clínico, seja winnicottiano. Supondo que eu seja um representante da transferência nômade à psicanálise que Kupermann sinaliza em seu trabalho (KUPERMANN, 1996, 2008), tudo o que posso dizer é que o pensamento de Winnicott me ofereceu guarida - sol e sombra -, pelo que me sinto feliz e grato. 


\section{PARTE I - APROPRIAÇÃO}




\title{
CAPÍTULO 1 - APRESENTAÇÃO OPERACIONAL DE CONCEITOS-CHAVE
}

\author{
Não pode haver ausência de boca nas \\ palavras: nenhuma fique desamparada do ser que a \\ revelou. \\ Manoel de Barros, Livro sobre nada
}

O campo de estudos da influência e da tradição na obra de um autor é vastíssimo; certamente seria imprudente e improcedente propor como tarefa a avaliação exaustiva do tema. Creio ser pertinente, nesse contexto, oferecer definições operacionais dos termos utilizados, sob pena de instrumentalizar a discussão e reificar proposições e para evitar usos "convenientes" dos termos a cada oportunidade, tendo "combinado" com o leitor o que esses termos significam - ainda que essas definições possam não ser tão precisas e coerentes quanto eu gostaria que fossem.

\section{AUTOR E OBRA}

\section{Abertura}

Poder-se-ia dizer que autor é aquele que escreveu o texto. É uma definição pragmática e econômica: se a pessoa escreveu, ela é a autora; se não escreveu, não é. Essa definição funciona bem na maior parte das vezes. Em algumas circunstâncias, no entanto, ela deixa de dar conta do recado, e passamos a precisar de definições mais complexas e específicas.

Creio que essa definição pragmática não resista muito, seja onde for. Para os fins do presente trabalho creio que é preciso complexificar, inclusive porque estamos trabalhando com psicanálise, campo em que o nome do autor faz muito mais do que simplesmente determinar a pessoa que escreveu o texto. Uma demonstração simples é o fato de que ninguém consegue escrever "em psicanálise" sem citar no mínimo um psicanalista; outra demonstração é fornecida pelo próprio Freud ([1937] 1973c): "só pode falar de psicanálise quem tiver se submetido ao processo de análise", no qual "perceba" que o inconsciente e a primazia do sexual existem e funcionam - ou seja, não fala quem quer, fala quem é "autorizado" ao cabo de um processo.

Mais do que isso, no campo da psicanálise, os autores estão sempre imersos em jogos 
complexos de filiações e influências, e por isso mesmo o autor de um texto, bem como os autores dos textos em que tal texto se baseia, cumprem papel decisivo para "entender" ou situar o texto.

Não bastasse isso, temos que considerar ainda que estamos às voltas com a obra do autor, e não simplesmente com textos individuais, avulsos; acompanhamos os textos dele ao longo do tempo, tentando entender, para além dos argumentos dos textos em si, a sutil dança dos conceitos e das ideias daquele autor ao longo de sua vida. Faz-se necessária, portanto, uma definição operacional que supere a compreensão prosaica associada ao termo.

\section{Um busto de bronze, um rosto na areia}

Quando nasci, Winnicott já tinha morrido; nunca o vi. Eu não poderia, a rigor, saber absolutamente nada sobre ele, muito menos sobre suas intenções ao escrever seus textos ou sobre a relação que estabelecia com seus pares em Londres. O que sei, sim, é que os textos atribuídos a Winnicott foram recebidos como textos importantes no meio psicanalítico, foram considerados "fundadores de um novo campo de estudos", foram citados e estudados; sei também que Winnicott (como nome de certa "força de gravidade" na psicanálise) tornou-se objeto de grande interesse e houve inclusive muitos que se dedicaram a procurar detalhes sobre a vida do homem-Winnicott, homem ao qual se atribui a autoria dos textos; muitas vezes se propuseram a articular a obra - o conjunto de textos atribuídos a Winnicott - ao homem que os escreveu, compreendendo que a partir de um entenderiam melhor o outro.

Como instituição, o autor está morto: sua pessoa civil, passional, biográfica, desapareceu, desapossada [...]; mas no texto, de uma certa maneira, eu desejo o autor: tenho necessidade de sua figura (que não é nem sua representação nem sua projeção) (BARTHES, [1973] 2010, p. 35).

O autor, ainda que esteja morto como "pessoa civil", persiste como influência na leitura na medida em que é "desejado" em tal ato; no caso da psicanálise - que não é exatamente o que Barthes tem em vista na passagem acima -, o desejo do leitor é reforçado pelo desejo da instituição e pelos jogos de poder que regem a leitura no contexto da disciplina. É por isso que quando falo de Winnicott não falo da pessoa que foi Winnicott, e no entanto tenho em mente seu rosto e a pessoa que unifica a obra. É por isso que quando me remeto a um dado biográfico acerca de Winnicott sei não estar tratando do homem-em-si que um dia foi Donald Winnicott, mas da ficção que se construiu "por trás" da obra atribuída a ele 
e que funciona como remissão do desejo do leitor - quando um psicanalista se autoriza "como winnicottiano" ou a partir dos textos winnicottianos, ele acha que "entendeu Winnicott", e afirmo aqui que esse Winnicott que ele entendeu não é a pessoa que viveu e morreu, e sim o que a instituição psicanalítica construiu para si como "busto de bronze".

Acontece nesse tipo de circunstância, e certamente acontecerá ao longo deste trabalho, um jogo de linguagem elaborado ao qual vale uma menção; o autor que se dispõe a comentar um texto o faz em articulação com um pensamento sobre o autor do texto comentado, e inscreve o texto no horizonte do que seriam os interesses pessoais do tal autor influente (se eu, por exemplo, dissesse "Winnicott sempre quis que...", isso aconteceria pela simples razão de que eu não tenho como saber o que Winnicott queria ou não queria); a mim fica claro que não se trata, de forma alguma, de fazer uma "psicanálise" do autor como paciente ou do texto como sintoma: o que se passa é que a imagem do autor cumpre um papel na forma como o texto é lido, e esse "autor" que não é a pessoa que escreveu a obra muitas vezes é organizado em torno de uma biografia. É recorrente que, a partir daí, tudo se passe em curto-circuito e as pessoas efetivamente acreditem que conhecem a vida íntima da pessoa que um dia foi o autor da obra; no meu jeito de entender esse aspecto, tal confusão não se apresenta, e quando falo do autor Winnicott não tenho em mente a pessoa que ele foi e não pretendo fazer sua psicanálise, nem sua psicanálise aplicada, nem sua psicanálise selvagem - o que faço é uma incursão no campo de discurso e de estudos que se organiza em torno do texto de Winnicott ${ }^{6}$.

O funcionamento geral do que estou apresentando se aproxima muito do que Foucault retratou como o "desdobramento" de um livro ao longo do tempo:

Um livro é produzido, evento minúsculo, pequeno objeto manejável. A partir daí é aprisionado num jogo contínuo de repetições; seus duplos, a sua volta e bem longe dele, formigam; cada leitura atribui-lhe, por um momento, um corpo impalpável e único; fragmentos de si próprio circulam como sendo sua totalidade, passando por contê-lo quase todo e nos quais acontece-lhe, finalmente, encontrar abrigo; os comentários desdobram-no, outros discursos no qual enfim ele mesmo deve aparecer, confessar o que se recusou a dizer, libertar-se daquilo que, ruidosamente, fingia ser (FOUCAULT [1972] 2004, VII).

Minha divergência aqui é que o livro não é, para mim, um "pequeno objeto

\footnotetext{
$5 \quad$ A imagem remete ao busto de bronze erigido em homenagem a Freud em Londres em 1970, para o qual Winnicott contribuiu com afinco na busca de recursos e na divulgação. Posteriormente um busto de bronze do próprio Winnicott foi erigido em outro local, mas também em Londres.

Sobre essa ordem de problemáticas em torno do estatuto do biografismo, remeto o leitor interessado à introdução e ao capítulo 6 (A biografia intelectual) do livro O desafio biográfico - escrever uma vida, de François Dosse, que desenvolve o tema de forma delicada e refinada (DOSSE, [2005] 2009).
} 
manejável", mas é, já ele, resultado de certo tempo de embate entre uma pessoa e as influências que a marcam - resultado e testemunho desse tempo, dessas marcas, e do que a partir delas (e apesar delas) se produziu.

\section{Definição provisória}

Considerando tudo o que foi exposto, portanto, sugiro a seguinte definição: autor é o organizador sempre provisório para o conjunto de influências e determinações a partir das quais um texto encontra pertinência dentro de uma disciplina discursiva específica ${ }^{7}$.

Curiosamente, a definição de obra que estou implicitamente propondo é bastante similar. Considero obra uma organização ficcional do que seria a superfície plena construída por um autor. Quando alguém se remete à obra de Winnicott, dificilmente tem em vista a soma de páginas e frases e textos, e sim certa fantasia que constrói para si como sendo o legado de Winnicott; esse legado é justamente o campo de verdade em que se podem instalar aqueles que tomam Winnicott como autor de referência e que, a partir de sua filiação a Winnicott, supõem "saber" a obra de Winnicott e, sabendo-a, dizer coisas no campo de verdade que Winnicott criou.

Tentei apresentar uma definição operacional do que terei em vista quando tratar do autor e da obra ao longo do trabalho. É, certamente, uma definição complicada; a vantagem que espero que ela tenha é manter explícita a tensão que existe no campo da autoria dentro do contexto da psicanálise e dentro da obra de Winnicott, ou seja: espero abordar a autorização em Winnicott como um processo de negociação em um contexto de influências e determinações sobrepostas, em meio às quais se pôde construir um "campo de verdade" singular, ao mesmo tempo uma ode e um desafio à história (psicanalítica, que esteja claro).

\section{INFLUÊNCIA}

Pretendo oferecer uma definição inicial - que aos poucos ganhará maiores complexidades e contornos levemente distintos dos oferecidos neste momento do trabalho. $\mathrm{Ou}$ seja: afirmo as balizas da questão aqui de forma mais ou menos "telegráfica", para desdobrá-

\footnotetext{
$7 \quad$ Talvez seja importante ressaltar que, apesar de ter em alta conta as problematizações de Foucault a respeito da questão do autor, não posso creditar completamente a ele tal definição; isso porque Foucault não leva em consideração algumas dimensões interpessoais e intrassubjetivas que estou considerando pertinentes (CASTRO, 2009; FOUCAULT, 2004).
} 
las ao longo do trabalho.

O tema da influência na autorização de um escrito me ocorreu pela primeira vez a partir da leitura de Harold Bloom, que formula a questão em seu livro Angústia de influência - uma teoria da poesia. Hoje, no entanto, creio ter chegado a uma formulação da questão que diverge em alguns pontos daquela assumida por Bloom.

Bloom estabelece, a partir de seus estudos sobre o tema, uma tipologia da influência, em que sugere seis formas de relação do autor com seu campo de influências; não pretendo recorrer a essa tipologia. Pretendo, por outro lado, levar as menções de Bloom ao Édipo, ao complexo de Édipo, à teoria da sublimação e à pulsão de morte em Freud mais a sério do que ele mesmo o faz - pela simples razão de que o horizonte deste trabalho tem tudo a ver com essas discussões, diferentemente do caso do próprio Bloom, que escrevia para escritores e críticos literários.

Em seu texto Ansiedade de publicação, Ronald Britton situa Winnicott como um representante legítimo da questão da influência; a partir dessa autorização inicial me proporei a distribuir alguns dos elementos que acredito serem pertinentes a essa discussão. Pela "simpatia" do argumento, pela inscrição do campo e pela centralidade na discussão, posso dizer que, se meu argumento fosse uma cidade, o texto de Britton funcionaria mais ou menos como o "marco zero", o coreto da praça da matriz.

Considero a angústia de influência a partir de uma leitura inspirada pela metapsicologia psicanalítica, em que a angústia associada ao efeito limitante de uma autoridade que transcende e supera o sujeito funciona, ao menos em alguma medida, como uma reencenação da situação edípica. Esse entendimento não me autoriza, como leitor e como estudioso, a supor saber o que se passou entre Winnicott e seu pai ou sua mãe, nem a "interpretar" a obra na pior tradição da psicanálise selvagem; sustentadas essas condições éticas para a leitura, no entanto, a hipótese "metapsicológica" para a influência oferece maiores recursos para que se possa sustentar a tensão e a complexidade da problemática em causa; como bem afirma Freud, a metapsicologia (ou "a bruxa", como ele gostava de chamar) comparece como forma de sustentação da capacidade de pensamento do analista, impondo que este jamais ceda à tentação de acreditar mais na teoria que inventa do que na efetividade do encontro - encontro clínico no caso de Freud, encontro entre leitor e texto no nosso.

Colocadas em termos as considerações necessárias para evitar a análise selvagem, considero a hipótese da reencenação do Édipo um elemento importante para a discussão, na medida em que: 1 . permite cotejar as hipóteses dos autores tomados em consideração a partir 
de um lugar minimamente estável (essa estabilidade sendo a função da "metapsicologização"; 2. possibilita uma discussão da problemática com o amparo da tradição psicanalítica sobre o tema, basicamente em torno da problemática da angústia edípica e a problemática da constituição do superego; 3 . permite que se discuta de forma mais clara a peculiaridade da contribuição da obra do próprio Winnicott para o estudo do tema da autorização e da influência, na medida em que conclamamos as nuances teóricas das relações entre os autores, enriquecendo a discussão. Esta última consideração comporta amplas consequências para a pesquisa e para o campo, já que a contribuição efetiva da teorização de Winnicott situa-o simultaneamente em dois níveis distintos no trabalho: como objeto, sendo estudado como autor em meio a dilemas de influências e autorização, e também como referencial teórico, a partir de seus conceitos e de seus textos.

\section{Inscrever-se}

Considero, como disse, a angústia de influência tendo como horizonte a metapsicologia psicanalítica; para problematizar a incidência da influência sobre o autor no contexto de um campo discursivo, no entanto, tenho em vista o conjunto de fenômenos que Foucault denominou "procedimentos internos" de atuação de poder sobre o discurso: o autor, o comentário e a disciplina (FOUCAULT, [1970] 2004, p. 21). Já tendo apresentado minha concepção de autor (que diverge em alguns aspectos daquela apresentada por Foucault), apresento a seguir em quê as concepções de comentário e de disciplina ajudam a entender a influência. Reiterando a montagem: considero aqui a influência - que é um campo de discurso e uma constrição das possibilidades de discurso - configurando uma angústia de influência, que é mobilizada no processo de autoria. Tratei do autor e da angústia de influência; tratarei a seguir da influência como campo.

Como já disse, influência é o efeito sobre o autor da tradição que o precede no campo em que ele se insere ou pretende se inserir - a forma como o que ele sente que tem a dizer se relaciona com o que naquele campo "se diz". Aquilo que ele percebe que "se diz" ou que já foi dito entre aqueles em meio aos quais procura reconhecimento age sobre o que ele tem a dizer; afinal, se ele quer ser reconhecido, tem que dizer algo que de alguma forma "continue" o que já foi dito, mas, ao mesmo tempo, se ele quer ser reconhecido, precisa se diferenciar dos demais de alguma forma. Monta-se aí um dilema; esse dilema, na forma como se apresenta ao autor, é o que aqui tomo como influência. Toda pessoa que se propõe autor lida com isso 
como pode, e seu trabalho (seu texto) representa, em alguma medida, uma proposta de equacionamento do dilema.

Uma das operações em causa ao lidar com esse dilema aparece no que Foucault chama de comentário, em que alguém se propõe a "dizer enfim o que estava articulado silenciosamente no texto primeiro" (FOUCAULT, [1970] 2004, p. 25). Nesse "dizer enfim”, o autor se propõe a dizer o que tem a dizer, afirmando, ao mesmo tempo, que o que está dizendo é "justamente" o que se diz nos textos de influência. A proposta do comentário é "dizer pela primeira vez aquilo que já havia sido dito" (p. 25), ou seja, assumir uma autoria inovadora e ao mesmo tempo propor-se signatário incondicional do texto (ou campo) de influência.

A disciplina não configura propriamente uma forma de "equacionar" o dilema da influência - é muito mais uma "regra do jogo". E essa regra, no caso, é que todos jogam usando um cabresto: antes mesmo de poder ser considerada boa ou ruim, verdadeira ou falsa, uma colocação deve ser considerada pertinente, ou seja, precisa "estar no campo". Nas palavras de Foucault ([1970] 2004, p. 33-34): "uma proposição deve preencher exigências complexas e pesadas para poder pertencer ao conjunto de uma disciplina; antes de poder ser declarada verdadeira ou falsa, deve encontrar-se "no verdadeiro"”.

Na prática, o que acontece é que a pessoa chega muitas vezes a um campo cheia de ideias e coisas a dizer, e vai aos poucos descobrindo que "a coisa é mais complicada do que isso": há que se considerar a história, o que já se construiu sobre o tema, a forma como as coisas acontecem... todas essas considerações razoáveis e necessárias constrangem o que a pessoa fantasia como sua obra e sua autoria, e esse hiato entre o impacto sonhado para as próprias ideias e a forma como os textos acabam sendo recebidos de fato aparece mesmo nos autores que se saíram melhor dentro desse "jogo". No caso de Winnicott, como já comentamos, a relação entre a tradição e a inovação, entre o comentário e a afirmação, comparece de forma marcada e central, tanto naquilo que ele fala sobre seu próprio processo de autorização quanto na forma como a teoria permite entrever o desejo do escrevente.

\section{Definição provisória}

Grosso modo, eu afirmaria que a influência diz respeito à forma como o campo de destinação do texto age sobre o autor na configuração do texto como afirmação; angústia de influência, por sua vez, diz respeito a duas coisas: por um lado representa a relação do autor com o campo em que se inscreve e, por outro, é a concretização no texto da constrição do 
autor em face da destinação que deseja para seu texto.

Como se vê, as definições de influência e de angústia de influência são muito mais delicadas e complexas do que as de autor e obra; acredito que isso ocorre em parte porque os primeiros termos estão em questão no trabalho, e serão mobilizados ao longo do texto. Espero, no entanto, que o leitor possa acompanhar a discussão com mais tranquilidade a partir dos esclarecimentos que puderam ser dados nessas definições operacionais. 


\title{
CAPÍTULO 2 - DÍVIDA E INFLUÊNCIA NO PENSAMENTO PSICANALÍTICO
}

\author{
De fato, nas Escrituras se lê: "Eis que ponho em Sião uma \\ pedra angular, escolhida e preciosa. Quem nela acreditar não \\ ficará confundido". Isto é: para vocês que acreditam, ela será \\ tesouro precioso; mas, para os que não acreditam, a pedra que \\ os edificadores rejeitaram tornou-se a pedra angular, uma \\ pedra de tropeço e uma rocha que faz cair. Eles tropeçam \\ porque não acreditam na Palavra, pois foram para isso \\ destinados. \\ Evangelho de São Pedro, 2 (6-8)
}

\section{DEVEMOS TUDO A FREUD}

Em uma carta bastante célebre escrita a Harry Guntrip (de 20 de julho de 1954), Winnicott afirma que todo psicoterapeuta deve tudo a Freud (WINNICOTT, [1987] 2005, p. 91-92). A justificativa que Winnicott oferece para essa afirmação peremptória é bastante simples: Freud dedicou sua vida ao trabalho de fundar a psicanálise, explorar o inconsciente e estabelecer o campo sobre o qual todo psicanalista que o sucede se insere. A tarefa de Freud, no entendimento de Winnicott, requeria grande dedicação e abdicação, porque

Freud podia facilmente ter seguido direto, intuitivamente, até chegar a verdades fundamentais, mas não era isso que ele queria. Ele queria pôr de lado toda a sorte de intuições tentadoras (as quais, no entanto, surgiram nas notas de rodapé e em observações esporádicas) e dar início a uma nova ciência, embora isso significasse concentrar-se no tantinho de trabalho que estava diante de seu nariz na época (WINNICOTT, [1987] 2005, p. 92).

Winnicott expõe aqui, de forma um tanto quanto "telegráfica", uma concepção bastante específica e pessoal da forma como a psicanálise opera. Acompanhemo-lo.

$\mathrm{Na}$ primeira oração da citação, Winnicott diz que "Freud poderia ter facilmente seguido direto, intuitivamente, até chegar a verdades fundamentais" - não é qualquer um que pode chegar facilmente a verdades fundamentais; de alguma forma Freud era dono de um talento especial, ele tinha potencial.

Potencial, de uma forma ou de outra, é poder. Freud, no entendimento de Winnicott, tinha à sua disposição a possibilidade, em virtude de sua potência de pensamento e visão aguçada, de chegar de forma quase inexorável a grandes descobertas. Winnicott acaba supondo que Freud poderia querer aprofundar suas investigações cada vez mais até chegar ao 
"umbigo" da questão - e de alguma forma parece compreensível e mesmo óbvio a Winnicott que ele tivesse esse desejo. Mas esse Freud, o Freud de Winnicott, não queria isso - ou melhor, ele queria, mas esse querer era um desejo "mais baixo", uma tentação a que estava sujeito (como ele implica ao dizer que Freud "queria pôr de lado toda sorte de intuições tentadoras"). E o Freud de Winnicott não se deixava abalar por seus desejos imediatos: ele tinha uma missão; ele queria dar início a uma nova ciência.

Dar início a uma nova ciência, no entanto, é uma tarefa sofrida para um homem como Freud; porque ele, que poderia "facilmente" ter chegado a verdades fundamentais, teria de se dedicar obstinada e metodicamente àquele tantinho de trabalho que lhe competia como fundador, aquele tantinho que "estava diante de seu nariz na época".

$\mathrm{O}$ que faria um homem com tanto potencial, que poderia chegar a verdades fundamentais, dedicar toda sua vida a conter-se, debruçando-se apenas ao tantinho de trabalho que enxerga diante de seu nariz? Por que alguém que aparece como um gênio em uma frase é apresentado trabalhando quase como uma toupeira na frase seguinte? E a resposta, fornecida pelo próprio Winnicott, é direta: porque ele estava dando início a uma nova ciência.

Freud, portanto, dedicou todo seu gênio em prol da criação de uma ciência - e é por isso que todo psicoterapeuta deve tudo a Freud; porque, como Winnicott diz em outro momento da mesma carta, o trabalho de todo e qualquer psicanalista "tinha de partir de algum lugar", e o trabalho de todo e qualquer psicanalista parte daquele tantinho de trabalho que Freud tinha à sua frente na época. No entendimento de Winnicott, Freud ofereceu seu gênio em sacrifício: em vez de entregar-se ao desejo de atingir verdades fundamentais, ele esmerouse na criação de uma ciência, e a partir dele todo psicanalista que produz - e tudo o que cada psicanalista produz - ancora-se em Freud, na obra freudiana; em vez de criar para si uma obra de profundidade única, Freud esmerou-se para produzir um campo, confiando que seus sucessores saberiam dar continuidade ao seu trabalho.

Uma das coisas curiosas na carta de Winnicott é que, pela forma como ele constrói as frases, a ideia de que todo psicoterapeuta deve tudo a Freud soa quase singela, como se essa dívida fosse uma dívida a ser cultivada - como se fosse um apelo à gratidão; a ideia, no entanto, não é necessariamente bonita: Freud seria um mega-credor e todos os psicoterapeutas estariam endividados com ele em tudo o que eles têm. Tomando certo distanciamento da ambientação da afirmação de Winnicott, pegamo-nos estranhando a situação: a ideia é demasiado dramática e soturna para ser apresentada em termos tão singelos; e, no entanto, não parece que Winnicott esteja floreando ou escondendo nada - a carta transpira sinceridade e 
assertividade. Por que esse hiato entre a evocação emocional proposta pela ideia que aparece na carta e o caráter um tanto perturbador da imagem que ela veicula?

Se existe uma razão sondável para isso, só poderemos encontrá-la mais à frente, quando estivermos analisando as angústias de influência conforme elas comparecem na imagem de autor de Winnicott no campo da psicanálise. Para evitar um estancamento diante de um desafio precipitadamente avançado, formularemos, de forma a poder prosseguir viagem, outro ângulo para a questão: qual é a natureza da relação entre a dívida de todo psicoterapeuta com Freud e a dívida em sua configuração corriqueira, entre, por exemplo, um devedor e seu credor?

\section{A CASA DA MOEDA PSICANALÍTICA}

Para Winnicott, como mencionei, todo psicanalista (ele fala em psicoterapeuta, mas acho o ajuste válido) deve tudo a Freud; acredito, no entanto, que essa dívida precisa ser olhada mais de perto, para que possamos compreender que tipo de dívida é essa e que influência ela tem sobre os psicanalistas - não é óbvio que todos em um campo devem tudo ao fundador desse campo, e se tal ideia é verdadeira, no caso da psicanálise, é primordial que possamos entender como ela funciona.

Uma sugestão interessante para a compreensão desse ponto é sugerida por John Forrester:

Para ler Freud, deve-se postular que ele efetivamente criou uma moeda, uma moeda psicanalítica, e que em posse de seu texto estamos segurando as notas de crédito desse sistema econômico. Depositar confiança em Freud é, portanto, como depositar confiança na instituição que emite notas de crédito ou notas bancárias. Os textos de Freud, portanto, devem ser tratados como notas promissórias, caso se deseje lê-los adequadamente (FORRESTER, 1997b, p. 113, tradução minha).

Forrester sugere que a relação do psicanalista a Freud é como a "dívida" daqueles que se engajam em atividades mercantis com o banco central - que emite as notas. E aí entra em ação um deslocamento grande: porque, nos termos de Forrester, não se trata de dívida, e sim de confiança: o que o banco central oferece àquele com notas é, também, um crédito, mas esse crédito não implica que um deve algo a outro - o primeiro estabelece bases para o segundo, que por isso confia que as operações que está fazendo têm lastro (têm base, têm solo). 
O horizonte da problematização de Forrester, vale lembrar, é outro: ele trata, nesse ponto da argumentação, da problematização de Lacan sobre o texto de Freud, situada simultaneamente no nível da confiança e no nível do crédito: o psicanalista deve dar crédito a Freud sem questioná-lo, deve confiar em seus textos e basear-se neles - sem escorar-se neles - para conduzir seu trabalho. O ponto em causa, implicitamente mobilizado por Lacan, é que Freud não pode ser questionado - Freud é o começo e o fim da linha, Freud se autoriza a si $m e s m o^{8}$. Daí deriva que há, sim, uma dívida a Freud, mas essa dívida é impagável - todo psicanalista deve, e todo psicanalista deverá, e deverá para sempre, tudo a Freud (e daí percebemos que a questão de Forrester é outra, mas não tão outra assim). Freud é o banco central da psicanálise, o sistema se funda nele, e atrás dele não há nada.

Será essa a natureza da dívida a Freud que Winnicott menciona em sua carta a Guntrip? Se for, a observação de Winnicott, presente na mesma carta, de que "meu ensaio sobre regressão não faria sentido algum se surgisse num mundo que não houvesse sido preparado para ele por Freud" assumiria um contorno bastante expressivo: não fosse por Freud, os textos dos psicanalistas não valeriam nada.

Reforça essa hipótese, ainda, a crítica que Winnicott faz a Fairbairn nessa mesma carta: Winnicott afirma a Guntrip que o propósito professado por Fairbairn, de "suplantar as teorias de Freud", é desnecessário, e que Fairbairn "estraga um livro muito bom com isso". De fato, se a perspectiva é de que Freud é quem emite as notas de valor dos textos em psicanálise, o eventual suplantamento de Freud por Fairbairn geraria uma "crise de confiança" em toda a psicanálise; mais do que isso: o suplantamento de Freud é impossível, mas se configura como um ataque à fundação mesma da psicanálise - angaria muitos inimigos, não funciona em quase nada e "estraga" o que poderia, sem isso, ser uma proposta boa.

Não se trata, portanto, de superar Freud; e, no entanto, supõe-se que um psicanalista que se dispõe a escrever deve ter alguma coisa a dizer que Freud não tenha dito ${ }^{9}$. A diferença maior entre o sistema de circulação de crédito e dívida no mundo financeiro e a circulação de crédito e dívida na psicanálise é que nesta a alienação não é favorecida e, pelo contrário, deve

\footnotetext{
8 Espero que fiquem claros ao leitor os pontos de destinação dessa autorização: do ponto de vista da auto-análise, da influência, e da autoridade. Como Agamben demonstra em Homo Sacer (em acordo com a discussão de Forrester), o governador se insere fora do sistema de governo, ele é o ponto vazio de fundação e manutenção da ordem; Freud é quem cria as regras, e é a exceção legal à regra (AGAMBEN, [1995] 2010).

$9 \quad$ Talvez fiquemos tentados a pensar aqui que em toda ciência algo semelhante se passa: a psicanálise tem seu Freud, a medicina tem seu Hipócrates, a Física tem seu Galileu. A coisa, no entanto, claramente não funciona assim:Freud é insuperável, como todo "fundador de ciência" é, mas para além disso, e principalmente, todo analista deve se haver com sua dívida a Freud para poder afirmar algo em psicanálise. "O pensamento psicanalítico não é uma religião, não mais do que não é uma ciência ou uma filosofia; é algo radicalmente novo e irredutível a qualquer uma destas categorias" (STEIN, 1988b, p. 41).
} 
ser posta em questão para conseguir crédito - o acúmulo de crédito não afunda o autor no sistema alienado, mas situa-o na "franja" da questão, no ponto de estofo do dilema da influência. Quem se propõe a ser psicanalista, e como psicanalista se propõe a ser autor, deve necessariamente se haver com a dívida que tem em relação a Freud e com o desejo que nutre de se afirmar por si só; se lembrarmos, no entanto, que Freud é o único na psicanálise a se afirmar por si só, teremos montado o dilema sobre o qual se instala o analista, do ponto de vista de sua autorização e de sua influência.

\section{NÃO-VIOLÊNCIA E FURTO}

Há mais um ponto da carta de Winnicott a Guntrip sobre o qual é importante nos determos para abordar a relação do psicanalista com Freud; consiste em outra declaração bastante famosa, em que Winnicott afirma que quando escreve assume que "as pessoas conhecem seu Freud e estão familiarizadas com a teoria em desenvolvimento". Essa passagem é muito citada em discussões sobre a relação de Winnicott com Freud, tendo em mente que ele dificilmente cita Freud e que a linguagem que usa remete muito pouco à linguagem habitualmente associada ao "freudismo", em que a metapsicologia é uma referência constante e onde se fala muito sobre o psiquismo do sujeito. O contexto de meu interesse é similar, mas gostaria de apontar para dois outros aspectos da frase.

Ao afirmar supor que as pessoas conhecem Freud, o que ele põe em causa é a escolha de não "explicar" Freud em seus textos. Com isso ele se expõe ao risco, obviamente, de que seus leitores, fazendo uma leitura desatenta de seu texto, deixem de perceber os pontos da teoria psicanalítica que ele está pondo em jogo a cada momento, e com isso deixem de perceber a importância ou a inovação, ou o tradicionalismo, no que afirma; podemos dizer que ele retoma aqui, pontualmente a respeito de Freud, a famosa frase do texto "Desenvolvimento Emocional Primitivo":

Não pretendo apresentar em primeiro lugar uma resenha histórica, mostrando o desenvolvimento de minhas idéias a partir das teorias de outras pessoas, porque minha mente não funciona dessa maneira. $\mathrm{O}$ que ocorre é que eu junto isto e aquilo, aqui e ali, volto-me para a experiência clínica, formo minhas próprias teorias e então, em último lugar, passo a ter interesse em descobrir de onde roubei o quê. Talvez este seja um método tão bom quanto qualquer outro (WINNICOTT, [1945] 2000a, p. 218).

A despeito dos riscos que corre, no entanto, Winnicott parece pôr em operação com 
essa escolha estilística um deslocamento interessante: os leitores de seu texto precisam, a fim de se situarem, entender o que ele está tentando dizer, para só a partir daí poderem inferir onde Winnicott se situa no jogo de influência da situação psicanalítica e eventualmente tomar partido em termos de pertencimentos dogmáticos; como ele "rouba" as ideias que usa, fica impossível usar suas referências como uma tatuagem que o identifica a uma gangue ou a outra - na época, para identificá-lo como kleiniano ou como annafreudiano. Com isso, o que ele proporciona, em alguma medida, é uma inversão da "circulação de influências" conforme ela se efetivava (ou se efetiva) nas instituições de psicanálise, onde imperava (ou impera) o "digame com quem andas e te direi se concordo com o que dizes". Essa escolha, se efetivamente é disso que se trata, faz todo o sentido no contexto de desenvolvimento intelectual de Winnicott na psicanálise - contexto de Controvérsias ${ }^{10}$, de enrijecimento de "times" dentro da Sociedade Britânica em disputa pelo título de "verdadeiro representante" do legado freudiano; o "método" (na medida em que a citação acima reflete um método), a linguagem escolhida por Winnicott funciona como uma revolta não-violenta contra a política vigente, como um dispositivo com intuito desmobilizador ${ }^{11}$.

Mais do que isso, ainda: na medida em que não entrega todas as "credenciais" de onde retira a legitimidade do que diz, Winnicott se "afiança" unicamente na experiência clínica e na confiança que os leitores têm em sua análise pessoal e formação adequada. Quando, mais à frente no mesmo preâmbulo de texto, afirma que ouvindo e criticando o que ele tem a dizer os ouvintes poderão ajudá-lo a estudar a origem das ideias que ele apresenta, Winnicott se coloca como alguém que precisa não saber de onde as coisas vêm, e supõe que as críticas dos interlocutores denunciarão quem foram os "roubados", e em quê. Nessa medida, a declaração mais sincera para Winnicott talvez fosse dizer que supõe que as pessoas e ele mesmo conhecem seu Freud, e conhecem a teoria psicanaliticamente com alguma robustez.

Há aí um interessante elemento em causa: na conjunção do "roubo aqui e ali" e do "suponho que as pessoas conhecem seu Freud", Winnicott inscreve, dentro do clima hostil da Sociedade Britânica, algo muito parecido com o "retorno a Freud" que Lacan faria, apesar de fazê-lo de forma muito distinta (Winnicott supunha que seus leitores tinham seu Freud lido, e

\footnotetext{
10 Denominaram-se Grandes Controvérsias as disputas que tomaram a Sociedade Britânica de Psicanálise entre Anna Freud e Melanie Klein e seus respectivos filiados e aliados - disputa em torno da "herança" de Freud, do legado legítimo da psicanálise. As Controvérsias se entenderam desde a chegada de Anna Freud a Londres, em 1938, a 1945. Os principais documentos desse período são retratados no livro As Controvérsias Freud-Klein: 1941-1945, organizado por Pearl King e Riccardo Steiner (KING; STEINER, [1991] 1998).

11 Eu não afirmaria, no entanto, que Winnicott tenha consciente e explicitamente calculado esse elemento "estratégico" de seu estilo no horizonte da problemática institucional.
} 
Lacan nunca fez nada parecido). Porque, como salienta Forrester em sua exposição sobre a leitura lacaniana de Freud, jamais se tratou de citá-lo exaustivamente ou de deter-se sobre o texto de Freud; tratou-se, isso sim, de confiar no texto de Freud e depositar nele confiança (FORRESTER, 1997b, p. 110-115). De Freud se retira, certamente, o fundamento para as afirmações que se faz, mas não é Freud quem paga as contas que o autor cria - o psicanalista se funda em Freud, mas se afiança em si, em sua trajetória, em sua autorização ${ }^{12}$.

\section{EXCÊNTRICO E IMAGINATIVO}

Na medida em que foge à etiqueta da produção intelectual psicanalítica, abandonando as apresentações filiais no estabelecimento do texto, Winnicott põe em questão justamente o lugar da influência na criação em psicanálise; é esse o campo que estou mobilizando aqui, de forma um tanto tateante e intuitiva, pelo fato de Winnicott não ter exposto seu pensamento a esse respeito - e este trabalho tem como incumbência, portanto, articular seu pensamento teórico, estabelecido em torno de outros objetos, a essa dimensão "atuante", mas não teorizada explicitamente.

O posicionamento de Winnicott talvez represente uma renovação diante do problema enfrentado pela psicanálise à época - o do excessivo ajustamento e docilidade daqueles autorizados a se denominarem psicanalistas por intermédio da burocracia da instituição:

A auto-seleção cedeu lugar a um minucioso exame dos candidatos. Donde a
exclusão daqueles que são suspeitos de alterações mentais, dos excêntricos,
dos autodidatas, dos grandes imaginativos; em vantagem daqueles que, bem
acomodados e bem preparados, são trabalhadores o bastante para ambicionar
maior eficácia profissional (FREUD, Anna apud KUPERMANN, 2008, p.
34).

Winnicott se "autoriza" psicanalista ao cabo de um processo de análise didática, apresentando um trabalho de "prova de fogo" e todo o resto. Ao longo de seu processo, no entanto, afiançar-se-á cada vez mais em uma criatividade marcadamente singular, em detrimento da apresentação ostensiva de suas filiações e referências - autorização singular a que se dedica para que, ao final da vida, empenhe-se em fundar, retrospectivamente, seu trabalho no contexto da tradição psicanalítica.

12 As naturezas da identificação com Freud no caso de Lacan e de Winnicott, no entanto, são muito distintas, e isso tem consequências que ainda precisam ser mais bem estudadas. Considero, por exemplo, as problematizações levantadas por Conrad Stein sobre a "identificação com Freud" (STEIN, 1988b, p. 42-47), em cujo horizonte o trabalho de Winnicott nos surgiria como algo mais "sadio" do que o de Lacan. 
No geral, quanto à questão da dívida que se imbrica na influência e sobre a qual me detive nesse capítulo, acredito que, no caso de Winnicott, ela se baseia em "um paradoxo essencial, que deve ser aceito e não se destina à solução" (WINNICOTT, [1947] 1975, p. 203). Esse paradoxo se estabelece na dívida absoluta de Winnicott a Freud, reconhecida por ele, e que conviveu perfeitamente com o fato de Winnicott fundar-se em outros campos e autorizar-se de outras maneiras. Temos uma boa apresentação desse paradoxo nas conquistas maiores dos últimos anos de vida de Winnicott: por um lado, a organização de seu último livro, O brincar e a realidade, primeiro trabalho organizado como apresentação sistemática de um pensamento original e fundador (talvez o único lugar em que Winnicott se porta claramente como "fundador de uma tradição"), e que ele dedica a seus pacientes, que "pagaram para me ensinar" (WINNICOTT, [1947] 1975); por outro, a apresentação do busto de Sigmund Freud esculpida por Oscar Nemon e entregue em cerimônia grandiosa e solene em 1970 - Winnicott havia dedicado a energia que tinha e a que não tinha nos anos antecedentes como líder da comissão que conduzia e arrecadava fundos para a homenagem ao mestre na Sociedade (KAHR, 1996).

Winnicott roubava, sim; mas jamais sonegou. Entre o estilo "espontâneo" e o "narcisista", entre o "fundador de paradigma" e o "renovador do pensamento psicanalítico", em suma: entre a hagiografia e a recusa, repousa uma obra com um poder perturbador digno de atenção. Talvez uma das afinidades entre o pensamento de Winnicott e o de Nietzsche apontadas por Adam Phillips (PHILLIPS, [1988] 2007, p. x) seja essa suspensão da ética da dívida no seio da instituição psicanalítica. Se a psicanálise sofria, à época, com a docilidade dos candidatos e membros e com a normalização dos pertencimentos, Winnicott propõe um modelo de pensamento em que delega ao pensador, até as últimas consequências, a responsabilidade sobre si; assim como roubava desavergonhadamente, defendia o valor da agressividade, combatia a ideia de pulsão de morte e criticava, sempre que tinha chance, a ortodoxia e a idolatria. Foi necessária a criação de um paradoxo para que fosse possível a alguém roubar alguma coisa e declará-lo, como se roubar fosse um direito conquanto houvesse responsabilização por ele; foi necessário "progredir para trás", rever o próprio enquadramento da concepção de sujeito na psicanálise, para pôr em novas chaves a relação à dívida e a relação à autonomia.

À época do ápice das angústias de autorização de Winnicott (entre 1935 e 1945, grossamente), a psicanálise se encontrava em franca crise. Na França, a figura de Freud esvanecia ao fundo de uma psicanálise minguante, e foi como um profeta que Lacan veio 
propor o "retorno a Freud"; na Inglaterra, a figura de Freud instalava-se ao centro das discórdias, inconteste, e a fratria disputava entre unhas e dentes o direito de falar em nome do líder totêmico, e Winnicott assumiu um lugar muito mais delicado e paradoxal. Temos pela frente o desafio de abordar sem solução de compromisso toda a ambiguidade e complexidade de sua autorização, de sua assunção de influência no contexto britânico, nos termos do que seu processo teve de apaziguamento, de revolução não-violenta, de iconoclastia e - por que não? - de retorno a Freud.

Se os roubos de Winnicott têm uma função defensiva, como são defensivas as angústias de influência no pensamento de Harold Bloom, eles certamente tiveram, por outro lado, um impacto profundo e decisivo, e proponho que nos esforcemos para conciliar a interpretação das defesas da influência sobre Winnicott com os muitos e muito marcantes ganhos secundários que propiciou. 


\section{PARTE II - POSSE}




\title{
CAPÍTULO 3 - UM LUGAR À SOMBRA, UM LUGAR AO SOL
}

\author{
Ser o que se pode é a felicidade. \\ Não adianta sonhar com o que é feito \\ apenas de fantasia e querer aspirar ao \\ impossível. A felicidade é a aceitação do \\ que se é e se pode ser. \\ Valter Hugo Mãe, $O$ filho de mil
} homens

\section{APRESENTAÇÃO}

No capítulo 2, afirmei que o fato de Winnicott não explicitar suas ancoragens na tradição não implica que ele se situe ou tenha tentado se situar fora dela. Teve, portanto, um papel "negativo": o estilo de Winnicott não implica uma "recusa" ou um exílio autoimposto em relação à tradição.

Neste capítulo, pretendo:

1. discutir os custos do estilo de Winnicott (ainda o modelo econômico...); e

2. propor um modelo de compreensão para a influência no contexto da psicanálise um aprofundamento, portanto, em relação à "definição operacional" de influência apresentada anteriormente, que propunha os contornos do conceito.

É frequente citarem uma passagem de um texto em que Winnicott diz: "se houver algo que faça que não seja freudiano, gostaria de sabê-lo" (WINNICOTT, [1967] 2007, p. 437). O mais habitual é que essa passagem seja tomada como "testemunho" do caráter freudiano do pensamento de Winnicott, a citação sendo usada nesse contexto como resposta àqueles que consideram que ele não o seja. Gostaria de sugerir que possamos dar um passo de lado para fugir dessa discussão, que me parece pouco interessante, e pensemos em outra leitura para a afirmação: de onde está, creio que Winnicott não tem como saber quando é e quando não é freudiano, e isso se revela fonte de preocupação para ele ("se houver algo que faça que não seja freudiano, gostaria de [poder] sabê-lo"). O que sugiro nessa leitura é que Winnicott precisa escrever como escreve, e precisa pensar como pensa, com o que infiro que seu estilo pode até ser espontâneo e autêntico, mas é também uma resposta aos dilemas que enfrenta no contexto de seu pertencimento à tradição. Desdobro, assim, a outra afirmação de Winnicott a que inevitavelmente voltamos, e que já citei nesse trabalho: sobre a necessidade de Winnicott de roubar as ideias que usa. 


\section{OS OUTROS EM MIM}

Em janeiro de 1967, Winnicott foi convidado a dar uma palestra a um grupo de analistas britânicos que se denominava Clube 1952; o convite era para que ele explicasse a relação de sua obra com o pensamento de outros psicanalistas - e a partir daí vemos que já naquela época essa era uma questão...

Winnicott, como nos informam os organizadores da coletânea Explorações psicanalíticas (onde figura uma transcrição da referida palestra), escolheu nomear o encontro com o título "DWW sobre DWW" - DWW sendo, obviamente, a sigla para seu nome completo, Donald Woods Winnicott.

Por que ele fez isso? O grupo o convidou a discorrer sobre a relação de seu pensamento com o de outros psicanalistas e, em resposta, Winnicott propõe um título que poderia perfeitamente ser um curto-circuito: ele falando sobre ele mesmo, ou a relação de sua presença no grupo com sua obra, ou qualquer coisa que o valha. Poderíamos pensar que Winnicott se recusa a falar sobre outros autores.

Ou poderíamos pensar que ele entende que uma coisa é a outra: que falar sobre a relação de seu pensamento com o de outros psicanalistas é falar sobre ele mesmo. Como se ele dissesse que é impossível falar sobre a relação dele com outros psicanalistas "a partir de fora", porque ele só poderia acessá-la a partir de seu próprio pensamento; como se ele dissesse que

parece impossível falar a respeito do indivíduo sem falar sobre a mãe, porque a mãe ou a pessoa que se encontra no lugar dela é um objeto subjetivo - em outras palavras, não foi objetivamente percebido - e, portanto, a maneira pela qual a mãe se comporta faz realmente parte do bebê (WINNICOTT, [1967] 2007, p. 441).

Será que os autores de que Winnicott se alimenta são “objetos subjetivos" para ele?

Perante o tal Clube 1952, Winnicott se apresenta de certa forma arrependido por não haver feito as associações de seu pensamento com o de outros psicanalistas antes. Em sua fala inicial, ele já diz:

À medida que o tempo ia passando, dei-me conta cada vez mais de quanto eu havia perdido por não haver correlacionado apropriadamente o meu trabalho com o trabalho dos outros. Isso [...] significou que o que eu disse ficou isolado e as pessoas tiveram de dar-se a um monte de trabalho para chegar a ele. Acontece que é esse o meu temperamento e constitui 
uma grande falha (WINNICOTT, [1967] 2007, p. 437).

Algumas coisas ficam claras nessa passagem: a primeira delas é que ele já sabia antes que não associava apropriadamente seu trabalho com o dos outros; a segunda é que ele pôde perceber que isso tinha um custo, e que ele foi percebendo esse custo paulatinamente - sendo que o custo para ele é o isolamento de seu trabalho e o trabalho a que as pessoas têm de se submeter para "chegar" a ele; a terceira é que ele considera isso consequência de uma "falha" decorrente de seu "temperamento".

Acredito que essa passagem nos permite revisitar a citação da abertura de Desenvolvimento Emocional Primitivo (“de onde roubei o que...") em um aspecto importante: naquela passagem, ele diz que seu método de "roubar" aqui e ali as ideias em que se inspira é, provavelmente, um método "tão bom quanto qualquer outro" - isso é o que afirma em 1945. Vemos, no entanto, que em 1967 ele compreende esse seu método de forma diferente, já tendo passado o tempo necessário para que se desse conta do "quanto havia perdido"; mais do que isso, ele atribui em 1967 o método que empregou por tantos anos a uma "falha de temperamento".

Que Winnicott se disponha a abrir sua comunicação com uma afirmação tão sincera e contundente parece prova de grande clareza intelectual, não? Sem dúvida o estilo de Winnicott soa, ao menos a mim, uma demonstração continuada ao longo da vida de sinceridade intelectual; acredito, no entanto, que outras coisas entrem em jogo. E uma das maiores evidências nesse sentido surge a mim na forma como ele fecha o texto, onde diz:

Direi apenas que não sei se gostariam de debater alguma coisa disto ou se prefeririam ajudar-me, por carta, a corrigir-me e a reunir-me com as várias pessoas através do mundo que estão fazendo trabalhos que eu quer furtei, quer apenas ignorei. Não prometo segui-lo até o fim porque sei que vou continuar a ter idéias que pertencem ao lugar em que estiver no momento, e não posso deixar de fazê-lo (WINNICOTT, [1967] 2007, p. 443).

Confesso que fui tomado por certo assombro quando percebi a discrepância entre a abertura e o fechamento do texto - depois de abrir o texto em tom de "criminoso arrependido", reconhecendo o custo e a falta de modos da forma como trabalhou por anos a fio, ele encerra sua comunicação pedindo que mandem sugestões, se quiserem, mas afirmando que se exime de segui-las, porque as ideias que tiver vão pertencer ao lugar onde nascerem; ou seja: reconhece que errou e declara que vai continuar errando! 
Em 1945, no mesmo texto em que afirmou "roubar" as ideias, Winnicott escreveu: "ouvindo o que tenho a dizer, e criticando, vocês me ajudarão a dar o passo seguinte, que consiste em estudar a origem das minhas idéias" (WINNICOTT, [1945] 2000a, p. 219). Pelas afirmações que citei, podemos ver que esse foi um passo perante o qual ele hesitou muito e que teve muita dificuldade em dar; aparentemente cabe a outros, de fato, o "monte de trabalho" necessário para articular suas ideias às de outros psicanalistas, posto que a tal "falha de temperamento" ainda estava presente em 1967, e acho seguro afirmar que essa "falha", qualquer que fosse, acompanhou-o até o fim.

Talvez onde Winnicott descreva uma "falha de temperamento" resida algo próprio de seu caráter, que Goldman descreveu como "narcisista gracioso e performista nato" (GOLDMAN, 1993a, xviii); isso, no entanto, será abordado com mais vagar adiante (no capítulo 6, mais precisamente). O fato é que Winnicott caminhou o quanto pôde no sentido desse "passo" que ele sentia que precisava ser dado, passo que o levaria a incrustar seu trabalho no edifício psicanalítico, e há evidências suficientes de que, no final de sua vida, ele esteve praticamente obcecado com a necessidade de articular seu pensamento de forma coerente e apresentá-lo de forma acessível; talvez se possa dizer que, sem ter tido filhos, Winnicott dedicou seus últimos anos ao esforço de construir um legado a partir de sua história - legado que se reflete no esforço autobiográfico (interrompido), no esforço editorial, no esforço de clareamento de suas ideias. Enquanto vivia, Winnicott tentou dar vazão a tais espontaneidade e autenticidade, deixando àqueles à sua volta o trabalho de "retirar do caos" o que quisessem aprender com ele (GOLDMAN, 1993a, p. 117); quando começou a pensar em morrer, no entanto, passou a levar muito mais a sério o esforço de "proteger" suas ideias e seus pensamentos numa matéria que resistisse ao tempo e que pudesse ser apropriada por outros - como se tentasse envolver seu pensamento na película de falso self e aceitabilidade de que fugiu ao longo da vida ${ }^{13}$.

13 Estou ciente do fato de o conceito de falso self não dizer respeito a algo "ruim" em si, e que não é ruim que haja falso self na vida de alguém; por isso poder-se-ia pensar que é errôneo supor que Winnicott fugia do risco de um comportamento em que compareça uma dimensão preponderantemente associada ao falso self. A despeito de tal possibilidade, sustento essa hipótese, para a qual fornecerei mais argumentos no capítulo seguinte. Para antecipar um resumo do argumento, convido o leitor a supor que há, sim, uma dimensão moralista associada de forma subjacente à antinomia conceitual verdadeiro/falso self, relativamente a qual Winnicott defende um máximo de verdadeiro self e um mínimo de verdadeiro self como algo "bom". 


\section{O MESTRE E A MADONA}

Questionei, há alguns parágrafos, se os autores de que Winnicott se alimenta são objetos subjetivos para ele. Retirei os fundamentos para a questão de um elemento simples: sua afirmação de que teve dificuldade, ao longo da vida, em associar seu pensamento ao dos demais, que ele retoma em 1967 dizendo que continuará tendo "idéias que pertencem ao lugar onde estiver no momento". Nos dizeres de Roberto Graña, "o uso que Winnicott fez de seus objetos consistiu numa apropriação tão completa que lhe era difícil apontar, exatamente, os lugares de onde derivava o seu refinado saber" (GRAÑA, 2007, p. 16).

Como ele mesmo explica nessa comunicação ao Clube 1952, sua diferença em relação a Melanie Klein consiste em que, para ele, o ambiente não pode ser separado do estudo do indivíduo, porque, no desenvolvimento inicial, o ambiente faz parte do sujeito, e a "mãe" (ou quem quer que seja que alimente o sujeito) faz parte do psiquismo em desenvolvimento. A partir daí retirei os fundamentos da tal pergunta: se Winnicott não consegue trabalhar se referindo aos objetos que o alimentam, e se não consegue discriminar de onde rouba e o que rouba e de quem, talvez isso ocorra porque esses "trabalhos de outros psicanalistas" que contribuem para a formação de suas ideias sejam "parte dele".

Não poderíamos abordar um problema desse porte "de frente", mas somente "pelas bordas". Temos, no momento, de nos deter em um detalhe importante que entra em causa aqui: os autores que estudam a influência associam as figuras de influência a figuras paternas, e o objeto subjetivo é associado inevitavelmente à figura materna - que tipo de problema essa incompatibilidade pode gerar? Pois acabei levantando uma hipótese de "relação de influência" que situa os autores "roubados" por Winnicott no lugar de objeto subjetivo, na indiscriminabilidade eu-ambiente que caracteriza as relações iniciais entre a mãe e o bebê.

Talvez essa dificuldade tivesse me demovido de sugerir a aproximação que fiz entre a angústia de influência, a impossibilidade de "citar as fontes" em Winnicott e a mãe como objeto subjetivo, não fosse uma afirmação em favor dessa hipótese pelo próprio Winnicott, e nesse mesmo texto de 1967; falando de uma ideia de Margaret Little que se mostrou importante para ele, Winnicott diz: “de maneira que esse é um pedacinho de minha vida em que realmente obtive algo de outra pessoa, quase como se o houvesse furtado da bolsa de minha mãe" (WINNICOTT, [1967] 2007, 442). Salientando esse episódio como "pedacinho" 
em que obteve algo de outra pessoa, Winnicott ainda reforça, discretamente, a sensação de que, em outros casos, ele não tenha obtido coisas de outras pessoas, mas de objetos subjetivos indiscrimináveis dele. De qualquer forma, a associação de Winnicott desse episódio de influência discernível à "bolsa da mãe", Winnicott favorece que arrisquemos a proposição de uma influência despertando uma angústia relativa à imago materna, e não paterna.

E de fato é justo que voltemos nosso olhar, ao tratar de Winnicott, ao papel da mãe, ainda que em um tema marcado pela paternalidade. De forma alguma subscrevo àqueles que afirmam que Winnicott não aborda ou não leva em conta a influência do pai; levo em conta, no entanto, aquilo a que Goldman se refere:

Há certamente algo que pode ser chamado de viés maternal permeando os escritos de Winnicott. [...] De fato, Winnicott tinha uma identificação maternal tão forte que Katherine Whitehorn, em um artigo ao The Observer baseado em uma entrevista com ele, chegou a descrevê-lo como uma "Madona" (GOLDMAN, 1993b, p. 42, tradução minha).

Winnicott não renega nem abandona o papel do pai na constituição psíquica; parece inegável, no entanto, que ele enfatiza o papel da mãe. Talvez fosse apenas justo se, ao fim e ao cabo, um estudo da influência em Winnicott acabe enfatizando o papel da imago materna na influência e na autorização.

Mas quais são as consequências de se associar a influência à figura materna?

Respondo: as consequências são, ao mesmo tempo, enormes e muito pequenas. Enormes porque abrimos uma frente de discussão que inicialmente estaríamos dispensando; muito pequenas porque, a rigor, a abordagem do papel da mãe não desconsidera nem diminui o papel do pai. Na verdade, seguimos Winnicott quando afirma que "o leitor é convidado a lembrar-se, quando ler uma parte de meu trabalho, que as outras partes estão sendo deliberadamente excluídas, e não foram esquecidas. A linguagem de uma parte específica é inadequada para as outras" (WINNICOTT, [1988] 1990, p. 52). É claro que seria profundamente injusto esperar que o leitor tenha em mente todas as partes e todas as linguagens em todos os momentos. O ponto que Winnicott quer salientar é que "a dissecação das etapas do desenvolvimento é um processo extremamente artificial. Na verdade, a criança está o tempo todo em todos os estágios, apesar de que um determinado estágio pode ser considerado dominante" (WINNICOTT, [1988] 1990, p. 52). Incluir a dimensão da imago materna na influência não implica mudar o ângulo do problema, mas 
sim progredir para trás, considerando outra dimensão compondo a mesma problemática; essa dimensão talvez estivesse em operação já nas considerações fundadas na imago paterna, mas era como uma emolduração discreta, silenciosa, como se os autores supusessem uma relação primordial suficientemente boa com a influência. Com Winnicott, como fundação teórica e como exemplo, somos convidados a pensar que há outras dimensões mais primitivas de influência.

Quando afirma que estamos o tempo todo em todos os estágios, Winnicott põe em causa a não exclusão entre sua ênfase no desenvolvimento inicial do bebê em contato com sua mãe, o bebê de Klein e seu desenvolvimento psíquico inicial e as "pessoas inteiras" de Freud; Winnicott, "vindo da criança de Freud, passando pelo bebê de Klein até o recémnascido dele mesmo, observa a diferença e a vigência simultânea das diversas linguagens que vai adotando" (FIGUEIREDO, 2009, p. 60). Ou seja: considerarei o papel da imago materna nas angústias de influência, sem com isso desconsiderar ou pôr em segundo plano o já consagrado estudo da imago paterna na influência (que se baseia, em grande parte, na psicanálise e no papel do complexo de Édipo nesse contexto).

Vale dizer ainda que considero que a abordagem da figura materna e de seu papel na configuração das ansiedades de influência associadas ao pensamento criativo não reduz a problemática, mas adiciona uma dimensão a ser levada em conta; e é sempre importante lembrar que essa outra dimensão não é "mais profunda", já que, como diz Winnicott, “inicial não é profundo, um bebê precisa de tempo e desenvolvimento antes que a profundidade apareça, de maneira que quando se está retornando às coisas mais profundas não se vai até o início" (WINNICOTT, [1967] 2007, p. 442).

Inicial, portanto, não é profundo; tampouco o avanço no desenvolvimento implica superação dos estágios mais precoces. E ao tratar de uma problemática, é importante lembrar que as outras ainda devem ser consideradas; e a linguagem própria a uma etapa não é precisa ou adequada para as demais, o que não significa que se possa esquecê-la ou deixá-la de lado. Um tanto inebriados com a complexidade do desafio de habitar e aceitar tantos paradoxos simultaneamente, sigamos para a abordagem da influência e de suas problemáticas, apresentando as concepções desenvolvidas pelos textos da influência como "tradição paternal”. 


\section{UMA MATRIZ DE RELACIONAMENTOS DEFENSIVOS}

O livro A angústia de influência, publicado por Harold Bloom em 1973, é certamente um marco. Nele o autor propõe que as obras dos grandes poetas sejam abordadas (do ponto de vista da crítica literária) a partir das influências que marcam sua criação e da forma como elas se situam perante tais influências. Segundo o argumento do livro, toda a tradição poética moderna se consagra como uma luta dos poetas para superar seus predecessores, desfazendo a influência e acessando a inspiração, a "musa", em sua forma pura e plena. Como diz o autor, "na argumentação deste livro, tem-se a história poética como indistinguível da influência poética, uma vez que os poetas fortes fazem essa história distorcendo a leitura uns dos outros, a fim de abrir para si mesmos um espaço imaginativo" (BLOOM, [1973] 2002, p. 55).

Mais do que um referencial metodológico para a leitura crítica de poetas, Bloom configura uma teoria da poesia - e uma teoria bastante trágica em seus contornos. Para ele, a poética moderna nasce com Shakespeare, que é deixado à parte do estudo intencionalmente por ser o "ponto de partida", o fundador das influências na modernidade. Segundo Bloom ([1973] 2002, p. 29-60),

Shakespeare é o maior exemplo na língua de um fenômeno que fica fora do interesse deste livro: a absoluta absorção do precursor ${ }^{14} \mathrm{~A}$ batalha entre iguais fortes, pais e filhos como poderosos opostos, Laio e Édipo na encruzilhada, só isso é meu tema aqui. [...] Dizer que Shakespeare e influência poética são quase a mesma coisa não é muito diferente de observar que Shakespeare é o cânone literário ocidental.

Shakespeare é o ponto de partida para a instalação da poesia moderna; a partir dele, os poetas se acotovelam entre si em busca de um espaço à luz da Musa Inspiradora, e a briga vai-se tornando, evidentemente, cada vez mais dura conforme o tempo passa. Para o sombrio Bloom ([1973] 2002, p. 60), "parece justo supor que a poesia em nossa tradição, quando morrer, será auto-assassinada, pela sua própria força passada" ${ }^{15}$. Shakespeare é o

\footnotetext{
14 Essa passagem de Bloom sempre me remete à resposta de André Green, quando questionado sobre qual seria a maior novidade na psicanálise: "Freud" (FIGUEIREDO, 2009, p. 13).

Seu livro, apesar do pessimismo, não é uma profecia do apocalipse. Seu pano de fundo sempre foi a crítica literária e a "conversa de surdo e mudo" em que ela havia se tornado a seus olhos. Considerando que a crítica estava se perdendo em ressentimentos e críticas "culturalistas" que lhe pareciam vazias, Bloom estabelece a história da poesia moderna como um longo abismo, a partir do que supõe poder avaliar os trabalhos dos autores com maiores ganhos para a crítica. Não tratarei da "tipologia" que Bloom propõe para considerar os vários níveis e formas de atuação da influência na poesia porque não acredito que isso nos
} 
poeta que cria o campo, e a partir dele o campo se desdobra como pode - de forma notavelmente similar ao que expus no capítulo 3 como o papel de "instaurador de confiabilidade" no campo da psicanálise, à exceção da atuação da entropia que Bloom vê na poesia e que não parece funcionar no campo da psicanálise.

A meu ver, um elemento que confere maior impacto e penetração ao trabalho de Bloom é o fato de ele cunhar um espaço internamente tenso e irredutível para a leitura, evadindo-se às leituras exclusivamente culturalistas, históricas ou psicológicas. E isso a despeito da aparência de uma "edipianização" da leitura do texto. A esse respeito, o autor alerta:

Eu jamais quis dizer, com "angústia de influência", uma freudiana rivalidade edipiana, apesar de um ou dois floreios retóricos neste livro. [...] Qualquer leitor capaz deste livro verá que influência-angústia não se refere tanto aos precursores quanto é uma angústia realizada no e pelo conto, romance, peça, poema ou ensaio. [...] "Influência" é uma metáfora, que implica uma matriz de relacionamentos - imagísticos, temporais, espirituais, psicológicos - todos em última análise de natureza defensiva (BLOOM, [1973] 2002, p. 23).

Winnicott, apesar do que diziam seus detratores (RODMAN, 2003), não era um poeta; talvez o leitor sinta que a apresentação do trabalho de Bloom seja desnecessária, e o questionamento seria certamente legítimo. Optei por apresentar a hipótese central de Bloom em maior profundidade, no entanto, porque ela estabelece a base para a problematização acerca da relação de Winnicott com a influência nos termos da angústia, e foi necessário estender-me no trabalho de Bloom porque o próprio Winnicott nega a angústia, sendo que ela nunca aparece positivada por ele mesmo.

Tal como Bloom afirma na citação apresentada, não se trata de considerar a relação efetiva do autor com seus predecessores, mas sim de atentar para sua realização no e pelo texto. A angústia de influência não é uma "freudiana rivalidade edipiana", se com isso se quiser compreender que uma coisa se reduz à outra e que a relação de influência é uma "montagem da cena" edipiana, "Laio e Édipo na encruzilhada" per se. No entanto, pareceme justo - tomando o cuidado de não transpor a linguagem própria de uma situação a outra em que ela não é adequada - considerar com Winnicott que as problemáticas supostamente "superadas" do desenvolvimento emocional são retomadas a cada momento decisivo; por isso, mesmo que não se considere a influência como uma "atualização" do Édipo, as várias 
referências de Bloom ao Édipo no livro parecem mais do que um mero "floreio retórico".

Seguindo as ideias de Bloom, compreendemos que o autor, ao se propor a escrever um texto, encontra-se diante de um dilema: por um lado, ele se inspira em predecessores para construir e sustentar seu trabalho, enquanto, por outro lado, propõe-se a acessar a Beleza e a Inspiração de forma imediata, e por isso se vê, ao mesmo tempo, impelido e impedido pelo predecessor. $\mathrm{O}$ autor pode desenvolver em si uma relação com o Belo, à sombra e guarida do predecessor, mas, no momento em que se propõe a expressar a grandeza daquilo que nele se desenvolveu, percebe que está bloqueado pela sombra oferecida pelo predecessor, já que ele agora busca um lugar ao sol. Acredito que, partindo do pressuposto de que o dilema influência-autorização atualiza elementos do complexo edípico, podemos valer-nos das considerações acerca da problemática edípica para desenvolver a problematização desse dilema e poder, assim, melhor compreender Winnicott, o angustiado autor aqui em questão.

Ronald Britton (2003, p. 276), inspirado pela proposição de Bloom, situa o problema de forma clara:

Penso que a ansiedade de publicação é universal e tem duas fontes: uma é o medo de rejeição por parte da audiência primária pretendida; a outra é o medo de recriminação por parte de colegas afiliados e do possível exílio do convívio com eles. [...] Penso que ela emana do medo da crítica por parte de terceiros que são encarados como plenos de autoridade e do medo de desfiliação de colegas a quem o autor sente a necessidade de ser afiliado.

Britton situa a problemática da ansiedade do autor em processo de publicação no contexto da legitimação; é nessa chave, inclusive, que ele aborda a ansiedade de publicação que percebe em Winnicott - no contexto da "vontade de reconhecimento" de Winnicott diante de Melanie Klein e de Anna Freud.

Além da dimensão da legitimação e do risco de exílio (ou castração), apontado por Britton na passagem acima, gostaria de evocar outra dimensão que me parece crucial para a compreensão do problema: a dimensão temporal, de "prioridade" - assumindo, portanto, a prioridade e a autoridade como as duas dimensões essenciais da ação de "constrangimento" da tradição sobre o autor. Como Conrad Stein (1988b, p. 70) belamente define ${ }^{16}$ :

16 Stein faz essa afirmação no contexto da influência do analista sobre o paciente; fiz as adaptações necessárias no texto (poucas) para ajustá-la ao contexto da influência do predecessor sobre o autor "ansioso". 
Tomar o lugar que ele [predecessor] ocupa realmente não é abolir a diferença; e o desejo de expulsá-lo está aí apenas para sustentar uma ilusão: uma vez em seu lugar, nós o teríamos ocupado antes dele, como se pudéssemos nos tornar nosso próprio avô. Abolir a diferença seria ocupar ao mesmo tempo todos os lugares na linhagem, isto é, identificar-se com o próprio princípio desta linhagem. Assim, o engano [...] de realizar seu desejo e consequientemente abolir toda diferença toma a forma mais correta de uma transgressão da lei imposta pelo pai, lei que prescreve ao sujeito seu lugar na linhagem.

Se o autor "ansioso" pudesse ocupar todos os lugares na linhagem concomitantemente, teria então todos os seus problemas resolvidos, todos os seus desejos satisfeitos: enquanto avô, poderia "ensinar ao pai uma lição" (autoridade) e estar, do ponto de vista genealógico, literalmente "acima" da problemática da influência (prioridade); sendo o próprio pai, já seria o autor, já teria dito aquilo que luta para conseguir dizer sem dizê-lo (autoridade) e teria sido, ele mesmo, autor da obra que almeja para si (prioridade); e estando em seu lugar a partir da ocupação concomitante dos lugares todos, reservaria a si mesmo os louros das conquistas desejadas, sem tolher-se satisfações e conquistas como o "pai” o faz na vida real. O autor em crise fantasia, ao assumir todos os lugares na linhagem, que se estivesse lá as coisas teriam sido diferentes e as criações teriam sido tão boas $e$ melhores do que efetivamente são. A ansiedade instaura a fantasia a partir da qual se consegue simultaneamente um lugar à sombra e um lugar ao sol - é-se, ao mesmo tempo, o líder/inovador e o renovador/salvador, o inventor do novo e o renovador do velho.

$\mathrm{O}$ autor, quando se propõe a escrever, tem de lidar com o desafio de associar um pensamento criativo a uma tradição existente, e tem de se haver com o fato de que não tem autorização para escrever - a comunidade a que almeja pertencimento se baseia no que já conhece: se ele propõe mudanças, foge às bases de pertencimento; se apenas repete o que já está dito, não está sendo um autor (mas sim um papagaio). Tal como os próprios Bloom e Britton afirmam, cada um à sua maneira, a angústia associada à autorização é universal e incontornável; como talvez diria Winnicott, o paradoxo da busca simultânea de um lugar à sombra e de um lugar ao sol deve ser tolerado e não pode ser resolvido. Em cada autor esse paradoxo (essa angústia) se manifesta de uma forma específica e favorece a criação de um estilo peculiar, como se a problemática da influência produzisse no estudo da autorização um padrão fractal $^{17}$.

$17 \quad$ Fractal é um objeto geométrico que pode ser dividido em partes, cada uma das quais semelhante ao objeto original; em muitos casos, um fractal pode ser gerado por um padrão repetido. 
Os dilemas apresentados, da forma como os compreendo, situam a problemática da autorização em termos das angústias edípicas - a prioridade e autoridade do predecessor, o risco de exílio/castração e a interdição do acesso à Musa/Inspiração. Proponho que passemos, então, da "criança de Freud" ao "recém-nascido de Winnicott", tentando compreender - aproveitando as chaves e os elementos construídos até agora - como e se é possível considerar uma contribuição de Winnicott à problemática da influência e da autorização.

\section{UMA MOLDURA PARA OS RELACIONAMENTOS}

Em seu trabalho, Winnicott não dá muita ênfase ao papel do pai na constituição do psiquismo ou na estruturação do sujeito. Essa particularidade já levou muitos a afirmarem que o que ele fazia não era psicanálise, ou que ele menosprezava essa dimensão da constituição psíquica.

Muitos se levantaram em defesa de Winnicott ao longo dos anos, e não me parece necessário retomar a discussão tout court; suponhamos que Winnicott se deteve em outro aspecto do desenvolvimento subjetivo e que essa ênfase teve papel decisivo em seu desenvolvimento teórico e em seu estilo clínico. Não sendo relativistas ou superficiais, podemos compreender que esse estilo e essa ênfase têm consequências para a estruturação do pensamento do autor, sem com isso considerar necessário julgá-lo "membro" ou não da psicanálise, devendo, ao mesmo tempo, estarmos atentos para as implicações da problemática abordada por Winnicott em relação ao campo da psicanálise como um todo. Considerando o papel do pai para a teorização da influência e da autorização a partir dos trabalhos de Bloom e Britton, é possível supor que a singularidade da abordagem de Winnicott pode sugerir nuances e ângulos diferentes para a abordagem do problema.

Clancier e Kalmanovitch ([1984] 1987) afirmam:

Preocupado principalmente com pacientes psicóticos ou crianças muito novas, sua atenção foi atraída para os estágios pré-genitais; isso não impediu que enfatizasse o papel do pai desde o princípio ou que declarasse que se a mãe não tivesse um marido que a apoiasse, ou mesmo se não catexizasse o pai da criança, o desenvolvimento psíquico dessa criança seria prejudicado (p. 95, tradução minha).

As autoras fundem duas respostas à mesma questão. No começo da citação, 
afirmam que Winnicott não enfatizou o papel do pai em seus trabalhos por estar preocupado com subjetividades que chamavam a atenção para a dimensão pré-genital, implicitamente sugerindo que o papel do pai conforme é "cobrado" de Winnicott diz respeito ao desenvolvimento da sexualidade genital; ao final, afirmam que ele enfatiza, sim, o papel do pai, mas em relação a outra dimensão do papel paterno. No primeiro movimento, consideram que o papel do pai que os autores procuram e não encontram só vai surgir com os estágios genitais do desenvolvimento, e que, por preocupar-se com estágios mais precoces de desenvolvimento, Winnicott não se debruça sobre a questão; no movimento seguinte, afirmam que ele aborda, sim, o papel do pai - mas outro, não aquele esperado.

Outeiral e Celeri $^{18}$ admitem basicamente duas "funções paternas" no desenvolvimento inicial do bebê conforme abordado por Winnicott: a primeira delas diz respeito à garantia das condições para a preocupação materna primária ou o "emolduramento" da unidade mãe-bebê, que é seguida - temporal e teoricamente - pela função paterna de ser a primeira pessoa inteiramente externa ao bebê com quem ele trava contato não-traumático (quando tudo vai bem), participando como "coadjuvante privilegiado" no processo de desilusionamento do bebê. Quanto ao primeiro aspecto, afirmam: "O pai torna-se o agente protetor que libera a mãe para que esta se dedique ao bebê. Assim, ela é poupada da necessidade de voltar-se para fora para lidar com o mundo que a cerca no momento em que tanto deseja voltar-se para dentro" (OUTEIRAL; CELERI, 2002, p. 763, 771-773).

A função paterna delineada por Winnicott poderia ser considerada "menor", "desprivilegiada", se fosse entendida simplesmente como "pôr o pão na mesa"; qualquer um que tenha acompanhado a etapa final de uma gestação e os primeiros momentos de um bebê na relação com sua mãe sabe, no entanto, que a "provisão ambiental" em causa aqui é muito mais complexa que isso. E a mãe que imerge nessa relação com o bebê precisa estar amparada psicológica e materialmente, posto que passará com o bebê por um processo que, desguarnecido, é um processo "patológico" - a mãe não consegue garantir sua sobrevivência ou a do bebê sozinha, em função de sua devoção ao processo pelo qual

18 Embora hoje esteja claro para mim que Winnicott tem uma teorização consistente no que diz respeito ao papel do pai, esse ponto é pouco enfatizado e brevemente abordado na maior parte de sua obra. De fato, não sei se eu teria conseguido abordar o tema se não fosse pela sistematização oferecida pelos autores citados. 
ambos passam.

Há ainda outra dimensão da função paterna própria à teorização winnicottiana apontado por Outeiral e Celeri, que é o papel do pai como "primeira pessoa completamente não-eu", e esse papel é bastante marcado no próprio processo por que passa o bebê, porque mesmo que "a relação com a mãe assuma uma nova dimensão quando acaba a fusão, para o bebê e para a criança pequena a mãe ainda retém uma característica subjetiva, pois é parte de sua função estar disponível para uma volta ao estado de fusão sempre que o bebê precisar" (OUTEIRAL; CELERI, 2002, p. 772).

$\mathrm{Na}$ medida em que abandonamos o momento da dependência absoluta e da indistinção entre eu e não-eu, passamos a lidar com as complexidades e os paradoxos da relação de objeto conforme elaborada a partir de Winnicott. Ele propõe uma mudança no conceito psicanalítico de "princípio de realidade" quando afirma que a realidade é construída pelo sujeito, e que a possibilidade de que a realidade atue como frustração ou como parâmetro ou como imposição ao sujeito depende de sua construção subjetiva - por isso, afirmo que, se o pai aparece nesse momento como "primeiro objeto não-eu", isso não é necessariamente tranquilo, e certamente está associado aos processos de construção subjetiva atravessados pelo bebê. E o bebê que percebe seu pai como um não-eu, usando-o na constituição da realidade, está passando pela

coisa mais difícil, talvez, do desenvolvimento humano; ou a mais incômoda de todas as falhas iniciais que devem ser cuidadas, [...] a localização por parte do sujeito do objeto fora da área de controle onipotente; ou seja, a percepção pelo sujeito do objeto como um fenômeno externo (WINNICOTT, [1968] 2010, p. 120, tradução minha).

Se de fato é disso que se trata, então esse papel do pai diz respeito à passagem, genialmente elaborada por Winnicott, da relação de objeto ao uso de objeto. Para ele, a psicanálise havia se dedicado bastante à questão das relações de objeto e tinha muito a dizer sobre o processo, mas havia muito pouco material disponível no que dizia respeito ao uso de objetos (WINNICOTT, [1968] 2010, p. 115). Essa, na verdade, parece ter sido a pedra de tropeço de Winnicott: incrustar no pensamento psicanalítico, e no sujeito psicanalítico, e na relação do sujeito com o ambiente, a presença do ambiente e do favorecimento ambiental ("o que está no sujeito já esteve fora, e o que está fora já esteve lá, e o que é dentro também é fora", e o paradoxo deve ser aceito e não resolvido).

Considerando que a psicanálise havia proposto a abordagem do "espaço interno" 
das pessoas, e que os demais "saberes" procuravam compreender as pessoas a partir do "espaço externo", ele afirma: "estou tentando chegar ao espaço entre esses extremos" (WINNICOTT, [1968] 2010, p. 141).

Há um espaço potencial entre o espaço psíquico que chamamos de subjetividade e o que chamamos de objetividade, que é o que situamos fora de nós mesmos. Se esse é o convite de Winnicott, talvez encontremos suas maiores contribuições à questão da autoria e da influência em outro lugar que não em sua problematização sobre a função paterna. Talvez sua maior contribuição esteja - se isso é possível - na reversão do dilema do autor em um paradoxo e na proposta posterior de aceitação do paradoxo.

Com isso, o dilema de estabelecer-se à sombra ou procurar um lugar ao sol passa a ser um paradoxo: o autor constrói seu lugar à sombra de seu predecessor, encontrando lá a porção de sol de que precisa, a partir do uso que faz de seu predecessor. O "tantinho de trabalho" que Freud tinha à sua frente está presente em todos os trabalhos de todos os outros psicanalistas, que se situam em sua prática à sombra fornecida por Freud, à luz das descobertas de Freud. O predecessor frustra o "autor ansioso" com sua existência independente-do-autor; o autor irado afirma "eu o destruî", e o predecessor está lá para receber a comunicação.

“A partir daí o sujeito diz 'olá, objeto!, eu o destruí. Eu te amo. Você tem valor para mim por ter sobrevivido à minha destruição de você. Enquanto eu estou te amando eu estou todo o tempo te destruindo em minha fantasia (inconsciente)"' (WINNICOTT, [1968] 2010, 120-121).

Talvez a contribuição mais incisiva de Winnicott ao campo da influência e da autorização seja esta: sugerindo que todos os processos superados continuam em desenvolvimento conforme o sujeito segue sua vida, e afirmando que as linguagens específicas não são apropriadas, mas devem ser levadas em consideração, Winnicott imbrica a tradição na criação, e a criação na tradição, desmobilizando o sistema de autoassassínio que, ademais, estaria em operação nos jogos de influência. Talvez Clancier e Kalmanovitch estejam certas quando afirmam, como o fizeram no trecho citado, que Winnicott não enfatizou o papel do pai por ocupar-se de psicóticos e recém-nascidos; mais do que isso, no entanto, ele não enfatiza o papel do pai conforme seria esperado de um psicanalista comportado, porque ele subverte a primazia do princípio de realidade e da frustração.

Na compreensão de Winnicott, a possibilidade de se relacionar com objetos 
depende de conquistas anteriores: a possibilidade de existir, a possibilidade de existir no tempo, a possibilidade de separar o mundo "lá fora" do mundo "interior". Para ele, essas conquistas são construídas na relação inicial do bebê com a mãe, ao longo da qual não se pode falar em sujeito nem em objetos internos, e em meio à qual o mundo é primeiro onipotentemente criado, e depois destruído para, só então, passar a existir como objeto. Winnicott embute uma dimensão de constituição entre o nascimento do bebê e o surgimento do aparelho psíquico conforme abordado por Freud e por Klein; essa problemática trabalhada por ele poderia ser considerada um "especialismo", a "psicanálise para recém-nascidos", se ela não operasse retroativamente sobre o pensamento psicanalítico estabelecido - o que não é o caso. O papel do pai como castrador, como frustrador, como iniciador do sujeito na "mediocridade cotidiana" que seria a vida, tudo isso é certamente posto sob suspeita por Winnicott.

Já sugeri antes que o modus operandi de Winnicott pode ser considerado como uma forma refinada de não-violência. Nesse caso, sugiro que a não-violência dele tem como reivindicação um lugar no sujeito para a criatividade não-ressentida, assentada sobre uma relação de criação, co-criação e destruição do predecessor; o pai (e, a partir dele, o ambiente), em Winnicott, muda definitivamente a problematização da influência. Dizem que Winnicott decidiu se tornar médico quando quebrou a clavícula, para que "nunca mais dependesse de um médico" (RODMAN, 2003; KAHR, 1996); podemos sugerir parodicamente que ele decidiu se tornar psicanalista para nunca mais depender de um pai (pai frustrador e castrador, que esteja claro).

Constantemente frisa-se que, para Winnicott, não existe originalidade se não a partir da tradição; o ponto curioso é que a própria tradição é criada: o criador cria o que existe, e só depois cria a partir do que existe. Como diz Brett Kahr: "As teorias de Winnicott anunciam sua própria originalidade; elas parecem exigir do leitor que busque as origens desse pensamento não na tradição, mas sim em um criador - D. W. Winnicott" (KAHR, 1996, p. xxiv, tradução minha). Winnicott se assenta na tradição, mas é ele quem inventa a tradição que segue - talvez não seja à toa que ele seja considerado representante eminente da Tradição Independente na psicanálise britânica. A paralaxe que Winnicott impõe à problemática da influência diz respeito à mudança na destinação da angústia: da angústia de autorização à angústia de autenticidade. 


\title{
CAPÍTULO 4 - AUTORIZAÇÃo E AUTENTICIDADE
}

\author{
Segue o teu destino, \\ Rega as tuas plantas, \\ Ama as tuas rosas. \\ $O$ resto é a sombra \\ De árvores alheias.
}

Suave é viver só. Grande e nobre é sempre

Viver simplesmente.

Deixa a dor nas aras como ex-voto aos deuses.

Ricardo Reis, "Segue o teu destino"

\section{VERDADES INCOMUNICÁVEIS}

O texto Comunicação e falta de comunicação levando ao estudo de certos opostos $^{19}$, de Winnicott, apresentado pela primeira vez em 1962, começa como tantos outros de seus textos: ele diz que "sua comunicação contém apenas uma ideia", "uma ideia bastante óbvia", e que "há uma considerável bibliografia sobre [o tema], mas não vou estudá-la ou apresentá-la aqui e agora" (WINNICOTT, 1962, in GOLDMAN, 1993a, p. 25). A rigor, trata-se de mais uma aparição da "falha de temperamento" a que Winnicott se referiria no Clube 1952, impedindo-o de articular o próprio pensamento ao dos colegas com quem dialoga e/ou em que se inspira - a não ser pelo contexto em que surge: nesse texto, Winnicott se debruça justamente sobre as formas como as pessoas se comunicam ou não com outras e como essas comunicações (ou não) se dão em termos da tessitura subjetiva envolvida.

Em resumo, a ideia é que há uma raiz não comunicável do sujeito e que parte do trabalho do analista consiste em oferecer e respeitar o espaço para a não comunicação no contexto do encontro, com o que se estabelecem as condições para o compartilhamento efetivo e o investimento criativo do paciente no espaço - condições para a habitação do

19 A meu ver, traduzir "not communicating" por "falta de comunicação", nesse contexto, consiste em um grave erro, já que Winnicott trata justamente do direito de não comunicar, com o que a ausência de comunicação não configura falta de nada. Sugeriria simplesmente "comunicação e não comunicação". Aproveitando o ensejo, gostaria de compartilhar que considero a tradução existente de $O$ brincar $e$ a realidade para o português bastante ruim, e espero que haja oportunidade editorial e científica para que o livro seja mais bem traduzido no futuro. 
espaço potencial e para o desenvolvimento da possibilidade de brincar. Essa ideia do texto se ancora em uma base mais fundamental e mais abrangente, que diz respeito à forma de operação dos opostos, e é nesse ponto que o texto de Winnicott é mais contundente e subversivo. No contexto da comunicação, Winnicott afirma que há dois opostos: 1. uma simples não comunicação; 2 . uma não comunicação que pode ser ativa ou reativa. $\mathrm{O}$ que chama a atenção nesse elencamento (como em tantos outros de Winnicott ${ }^{20}$ ) é que, para falar grosseiramente, a conta não fecha: além de o item dois ser desdobrado em dois subitens, ao longo das páginas seguintes Winnicott fará uma série de remissões internas de um tipo de não comunicação a outra, de forma que as possibilidades de comunicação e não comunicação transcenderão em muito a sistematização simplista que ele oferece (além de a oposição não ser, como se poderia esperar, entre comunicar e não comunicar). Por trás da enganosa sistematização didática há duas discussões concomitantemente em andamento: quanto aos opostos e às polarizações, e quanto à natureza da comunicação entre o verdadeiro self e o não-eu.

Em relação ao primeiro aspecto, Winnicott contesta a organização dicotômica de opostos em polaridades simples - além de morte, a vida tem como oposto possível a ausência de vitalidade; além da recusa da comunicação, a comunicação tem como oposto o resguardo da dimensão incomunicável do sujeito (o que não deixa de ser uma comunicação, do ponto de vista da experiência). Na apresentação dos opostos apresentados por Winnicott vemos, por exemplo, que não comparece a comunicação (itens 1 e 2 são formas de não comunicação) e o item 2 se desdobra posteriormente em função do desenvolvimento emocional do não-comunicador envolvido. Acredito que essa problematização da oposição dicotômica se entrelaça intimamente à importância do paradoxo no pensamento de Winnicott: quando ele diz que não devemos perguntar ao bebê se ele criou o objeto ou se ele já estava lá, entra em causa, entre outras coisas, a impertinência da separação dicotômica simples, da mesma forma como ela é questionada nesse contexto. Em outra dimensão do mesmo problema, Winnicott também questionou a oposição Freud-Klein no contexto do lugar da verdade na Sociedade Britânica, favorecendo a criação de um espaço de indiscernibilidade intermediário, encarnado historicamente pela Tradição Independente.

Além disso, Winnicott mobiliza a discussão para pôr em causa uma oposição que

20 Este elencamento ao menos não incorre na paródia borgeana de encerrar a lista com um último item “et cetera", como em $O$ destino do objeto transicional (WINNICOTT, 1994 [1959]). 
ele mesmo havia criado: aquela entre o verdadeiro e o falso self. O par de conceitos cunhado pelo autor foi muito discutido e muitas vezes criticado por favorecer certa moralização ou uma simplificação excessiva da teoria que os embasa, já que o primeiro impulso do leitor seria supor que o verdadeiro self é algo bom e positivo, enquanto o falso self é algo ruim e negativo. A despeito de si mesmo e de todas as problematizações que propôs, acredito que Winnicott tenha feito uma escolha ao cunhar os termos dessa forma e que haja, até certo ponto, investimento do próprio autor "pelo" verdadeiro self e "contra" o falso. Acho, mais do que isso, que a tal "falha de temperamento" que o impede de citar autores com quem dialoga ou em quem se inspira se articula com a "falha" consistente em cunhar termos com apelo moral pela autenticidade do verdadeiro si-mesmo e contra a falsidade da adaptação às demandas sociais.

O que estou afirmando, grosso modo, é que parece existir um desejo do autor favorecendo a simplificação dos conceitos que acabou ocorrendo - e esse desejo se liga à tal "falha de temperamento" que impede que Winnicott amarre seu pensamento com a tradição. No texto em questão, no entanto, ele parece mobilizar a questão em torno do verdadeiro e do falso self de forma mais refinada; a passagem que tenho em mente é a seguinte:

Estou introduzindo a ideia de uma comunicação com objetos subjetivos e ao mesmo tempo de uma não-comunicação ativa com aquilo que é objetivamente percebido pelo infante. Não parece haver dúvida que, a despeito de toda sua futilidade do ponto de vista do observador, a comunicação com objetos subjetivos carrega todo o senso de real. Por outro lado, tal comunicação com o mundo como ocorre a partir do falso self não é sentida como real; não é uma verdadeira comunicação porque não envolve o núcleo do self, aquilo que pode ser chamado de verdadeiro self (WINNICOTT, 1962, in GOLDMAN, 1993a, p. 29-30).

Essa cisão a que Winnicott se refere está aí sendo considerada em termos de um sujeito que tenha sido submetido a falhas consideráveis no desenvolvimento emocional primitivo. A proposta de Winnicott, no entanto, é que há uma dimensão desse mecanismo em operação na pessoa saudável, que se expressa na possibilidade de o indivíduo se comunicar silenciosamente com seus objetos subjetivos; nos termos de Winnicott, "há espaço para a idéia de que significativamente relacionar-se e comunicar-se se dá em silêncio" (WINNICOTT, 1962, in GOLDMAN, 1993a, p.30). O silêncio que se verifica na relação com o observador externo (no caso, o psicanalista) é uma dimensão necessária para uma comunicação construtiva e significativa, que é essa entre a pessoa e seus objetos 
subjetivos; o ponto é que essa "conversa interna" acontece justamente porque há um encontro não-comunicativo "lá fora" favorecendo-a e permitindo-a (i.e., a pessoa consegue estar sozinha na presença do outro). A pessoa saudável consegue mobilizar um encontro e torná-lo improdutivo aos olhos do observador externo, sendo que essa improdutividade configura o estado de relaxamento a partir do qual se pode entrar em contato com uma dimensão verdadeira de si mesmo.

Nesse aspecto, como em outros de sua teorização, Winnicott põe sob suspeita uma oposição estável pelo concurso de um terceiro elemento, a partir do qual os opostos iniciais passam a comportar uma dimensão do oposto em si mesmos; por exemplo: considerando o espaço potencial e a forma como ele se processa, o espaço intrapsíquico passa a conter em si uma dimensão do ambiente, assim como o ambiente passa a ser considerado em articulação íntima com o psiquismo que o aborda (é o sujeito que "cria" o mundo, que, no entanto é mundo; e o psiquismo é intimamente dependente do ambiente e das coisas sobre as quais ele pode investir seu potencial criativo). A mirada de Winnicott introduz um elemento de instabilidade na oposição, a partir do qual os opostos acabam tendo suas fronteiras "amolecidas".

O ponto para o qual quero chamar a atenção nesse contexto diz respeito ao lugar da autoridade. Sugeri que Winnicott desloca a calha por onde corre a angústia de influência no autor, transpondo-a da luta por autorização (contexto abordado por Bloom e Britton, como tratado antes) para a luta por autenticidade; a questão delicada nisso é que essa transposição não anula o lugar de autoridade como polo de destino do processo - sendo o "senhor de sua obra" ou sendo a "pessoa relaxadamente não-integrada", o autor ainda repousa sobre um lugar de autoridade, um trono. Dodi Goldman afirma: "uma das formas de compreender a teoria de Winnicott é vê-la como parte de sua batalha para descobrir o que ele poderia sentir como real". Essa forma de mobilizar o pensamento parece ter tido consequências curiosas e (talvez não por acaso) paradoxais: enquanto legado, Winnicott parece ter favorecido tanto uma influência pulverizada e relativamente imperceptível por pedir o uso e não a repetição de suas ideias como, por outro lado, um culto à figura do autor em virtude da pessoalidade e da pouca sistematização de seu pensamento (por favorecer a repetição e não o uso de suas ideias) $)^{21}$.

21 Brett Kahr afirma, a respeito da segunda tendência: "Buscando uma linguagem 'viva' na teoria psicanalítica, tendo a necessidade de redesenhar e retrabalhar as teorias dos outros para apropriar-se delas, Winnicott rejeitou a repetição da terminologia alheia, procurando ao invés disso criar sua própria forma de nomear". 
A angústia de influência, conforme apresentada a partir de Harold Bloom, manifesta-se no autor em processo de autorização pela necessidade de ser autorizado por e ao mesmo tempo autorizar-se perante a tradição; Bloom sugere que assim se configura um dilema perante o qual o autor se debate sem perspectiva de resolução possível - o autor pode aceitar a castração e resignar-se ou acabar-se em um confronto invencível. A contribuição de Winnicott passa pela possibilidade de roubar o que se pensa, inventar o que está lá para ser inventado, encontrar a luz na sombra; há quem diga que Winnicott compõe uma figura quixotesca no cenário psicanalítico de seu tempo: contanto que não se precise optar pela versão de Quixote ou dos observadores externos, e contanto que se aceite o paradoxo de um louco ingênuo que é um louco sagaz que é um cavaleiro destemido que é um herói sem causa, considero a imagem justa.

Marion Milner conta que uma vez Winnicott abriu uma aula dizendo a seus alunos: "O que quer que vocês peguem de mim, terão de retirar do caos" (GOLDMAN, 1993a, p. 117). É uma afirmação curiosa - os professores no geral consideram uma de suas atribuições tornar suas comunicações compreensíveis. Em Comunicação e falta de comunicação, citado anteriormente, Winnicott diz que "permitirá a si mesmo liberdade considerável para acompanhar seu tema onde quer que ele o conduza" (WINNICOTT, 1962, in GOLDMAN, 1993a, p.25) - ele fez isso ao longo de suas décadas de maturidade, e isso é bastante consistente com sua teorização. A questão é: que tipo de consequências esse expediente da parte dele impõe para o legado que ele deixa no meio - será que aqueles influenciados por Winnicott terão a mesma liberdade usando as ideias dele que ele conquistou para si? Se "os seguidores da sra. Klein são todos filhos e netos [e] os seguidores da srta. Freud foram todos à mesma escola" (WINNICOTT, [1954] 2005, p. 88, carta a Melanie Klein e Anna Freud publicada em $O$ gesto espontâneo), como descrever os seguidores de Winnicott?

Se essas considerações procedem e se a busca por autenticidade em Winnicott passa por aí, resta ainda sabermos de que maneira ela se configura enquanto imagem de autor. Isso porque, como ressaltei no primeiro capítulo, o autor é a sombra que estabelece os contornos de uma obra, e é a figura do autor conforme evocada no leitor pelo texto que oferece consistência à concepção de obra que se estabelece na posteridade. Se Winnicott se estabeleceu enquanto autor e se ele configura para sua obra autoridade, isso se deve em 
parte $^{22}$ à sombra de si que conseguiu constituir, e o fato de ele paradoxalmente borrar os contornos da autoridade que consegue para si não implica, de forma alguma, que essa autoridade não exista. Acredito que haja uma organização imaginária bastante consistente para esse processo, organização que se amarra em torno de uma imagem veiculada na biografia consagrada para o autor; é sobre esse ponto que proponho a sequência da discussão.

\section{O ESTATUTO DOS LÍDERES E DOS SEGUIDORES}

Lembrando da comparação de Winnicott, que disse que os seguidores de Klein eram como filhos e netos e os seguidores de Anna Freud alunos de uma mesma escola, questionei com que poderiam ser comparados os seguidores de Winnicott. Pois bem: antes de qualquer outra coisa, acredito que são seguidores de um líder empenhado em despistálos, como crianças brincando de "siga o mestre"; seguidores de um mestre que contorna postes, passa por baixo de mesas e faz piruetas para que não o sigam (apesar de estar aparentemente adorando a brincadeira). Além disso, acho que seguem alguém difícil de seguir: tudo indica que Winnicott não valorizava tanto suas ideias quanto a forma como ele as tinha e as empenhava. Uma colega de trabalho dele no Paddington Green disse que sentia que "era como se ele achasse que um punhado de Winnicott valia um quilo de psicoterapia pedestre" (GOLDMAN, 1993b, p. xix), e penso que isso se aplica mesmo à sua relação com suas ideias. No geral, parece-me que Winnicott vivia intensamente e acreditava muito na singularidade de sua experiência; o ponto mais curioso nisso é que ele parecia amar mais a si mesmo do que a suas ideias ${ }^{23}$.

Mas acredito que haja uma imagem mais clara e simples para definir a relação de Winnicott com seus seguidores. Retomando a brincadeira que ele mesmo propõe: se os discípulos de Klein são filhos e netos de uma família e os de Anna Freud foram à mesma

\footnotetext{
22 É claro que é importante considerar também a eficiência, a pertinência e a riqueza das ideias que veicula, bem como o trabalho de outros autores antes, durante e depois de sua vida que também trabalharam sob a sombra de Freud.

${ }_{23}$ Diferentemente de Freud, por exemplo (e até onde tenho notícias - Freud, como Winnicott, morreu antes de eu nascer e também não o conheci pessoalmente). Freud, destinado pelos pais a ser o gênio da família desde pequeno, tinha por principal hobby caminhar com os colegas de profissão catando trufas e cogumelos; afora as viagens semestrais, costumava trabalhar cerca de quatorze horas diárias, seis dias na semana, e era assustadoramente metódico. Winnicott, de sua parte, gostava de tocar e ouvir música, de dançar, de jogar, de praticar esportes - não gostava muito, por outro lado, de filosofia, livros eruditos e não prezava muito a intelectualidade. Teria sido um médico rural não fosse a psicanálise, e teria sido um psicanalista local não fosse o cosmopolitismo e afã editorial de Masud Khan.
} 
escola, os de Winnicott se inspiram num mesmo líder protestante. A grande dificuldade aqui é que as imagens que Winnicott propôs para os seguidores de Klein e Anna Freud “engancham" de maneira um tanto sarcástica na teorização delas, e certamente não quero propor que Winnicott incutia à sua teorização um tom religioso (embora, considerando a religiosidade em seus matizes mais ascéticos, a proposição não seja de todo descabida). No entanto, para dar continuidade à brincadeira também nesse nível, teríamos que imaginar que os seguidores de Winnicott seguiam um líder protestante que valorizava o processo de pensamento independente acima da própria convicção religiosa; para condensá-lo em uma imagem, teríamos algo como um profeta revolucionário, como Antonio Conselheiro... ou como Jesus Cristo ${ }^{24}$. É importante ressaltar que a independência de pensamento que profetas revolucionários como Jesus Cristo e Antonio Conselheiro valorizam diz respeito à ortodoxia e ao status quo, porque, em outro nível esses mesmos profetas valorizam justamente o apaixonamento inquestionado, a identificação - e é nesse ponto que entra a dimensão protestante, e paradoxal, da revolução para Winnicott.

É possível que, a esta altura, toda essa discussão pareça preciosista, se não simplesmente desnecessária - afinal de contas, o que esse devaneio sobre o caráter protestante da liderança de Winnicott como autor tem a ver com autenticidade, que é a discussão do capítulo? Acredito que tenha muito a ver. A ideia, no entanto, não é reduzir a obra de Winnicott ao estatuto de uma dogmatização religiosa - emprestando o rigor metodológico de Weber (que entendia de protestantismo como poucos, diga-se de passagem), eu diria que

procederemos tão-só de modo a examinar de perto se, e em quais pontos, podemos reconhecer determinadas "afinidades eletivas" entre certas formas de fé religiosa e certas formas de ética profissional [no nosso caso a fé religiosa de Winnicott e a ética subjacente a sua autoria]. Por esse meio e de uma vez só serão elucidados, na medida do possível, o modo e a direção geral do efeito que, em virtude de tais afinidades eletivas, o movimento religioso exerceu sobre o desenvolvimento da cultura material (WEBER, [1904-1905] 2004, p. 83).

A maior diferença, em vista da particularidade deste estudo, é que o interesse aqui

$24 \quad$ Percebo agora que antes nesse mesmo texto, na Justificativa, usei as mesmas imagens, diferenciando, no entanto, Jesus Cristo de um profeta - como se ele não o fosse. Sobre a aproximação, Robert Rodman se refere a essa "identificação" diversas vezes em seu livro (RODMAN, 2003), contando inclusive um episódio em que Winnicott teria confeccionado ao longo de uma sessão com Marion Milner uma figura de Cristo na cruz feita de palitos de dente, que talvez não por acaso esqueceu ao alcance da própria Milner. O poema de tom autobiográfico The Tree, escrito por Winnicott, também faz diversas referências a Cristo. Infelizmente não terei oportunidade de abordar mais a fundo esse ponto no presente trabalho. 
recai principalmente sobre a figura de autoridade que emana desta mesma informação religiosa. Por isso situamos nosso argumento acerca da autenticidade de Winnicott na zona de convergência entre a irônica análise da autoridade exercida pelas "dogmáticas" Anna Freud e Melanie Klein (considerando que ele certamente tem um papel nessa polêmica) e a metodologicamente precisa análise (como citada acima) das afinidades eletivas entre uma orientação religiosa e seus correlatos nos termos da ética profissional e cultura material. Ou seja: suponho que haja uma infraestrutura que sustenta a emanação de autoridade a partir de determinado autor: essa infraestrutura, no entanto, apresenta-se diferentemente em cada autor - na relação de autoridade de Klein com seus filhos e netos, de Anna Freud com os alunos da escola, de Winnicott com os seguidores da doutrina. Neste momento, estamos estudando a forma como a autoridade de Winnicott se configura, e para isso o trabalho de Weber - A ética protestante e o espírito do capitalismo - apresenta uma clareza metodológica exemplar.

Weber não quer demonstrar que o espírito do capitalismo é fruto da ética protestante; também não quer mostrar que é a semente da mesma ética. Supõe, na verdade, que há uma espécie de germinação recíproca para a qual não se poderia afirmar uma causalidade em linha única, a menos que fossem feitas séries e séries de estudos que se mostrassem exaustivos - aí, sim, poder-se-ia dizer quem veio de onde; mais ou menos, digamos, como Winnicott acredita que com o passar do tempo a ciência mostraria qual das partes em litígio na Sociedade Britânica tinham mais razão. Em ambos os casos sabemos e é bem possível que os autores já soubessem à época - das limitações da ciência em termos de superação da história. O trabalho de Weber, que muitas vezes anunciava ser o início de um trabalho de esclarecimento, mostrou-se esclarecedor até onde o esclarecimento pode ir - algumas questões não podem e talvez não devam ser resolvidas à sua exaustão.

Pois bem, algo similar se passa com a influência da ética protestante sobre a autoridade de Winnicott: as causalidades não são plenamente determináveis, e sucede uma espécie de germinação recíproca entre a ética protestante e o "espírito do psicanalista" espírito do psicanalista, no caso, como a imagem do autor, essa que se insinua sob o texto, costurando a obra, conferindo à posteridade uma autoridade estável na qual se fiar. 


\section{A FÁBULA DO AUTOR}

Não sou sociólogo, e a leitura que faço do livro de Weber é certamente limitada; pude perceber, apesar dessa limitação em minha leitura, um elemento organizador em seu argumento: há uma "base dura" do que ele considera ética protestante que se apresenta na compreensão por Calvino da ascese, e as diversas seitas e igrejas são como que deturpações no "plano das coisas" do que essa ascese apresenta como "plano das ideias". Apresentar o argumento de Weber aqui escaparia imensamente aos propósitos da discussão, e nem pretendo me aproximar do argumento de Weber no que tange ao capitalismo. O que vale frisar é que há uma valorização ascética das práticas terrenas, paradoxalmente, pela afirmação da incomunicabilidade entre o mundo terreno e o sagrado: Deus é insondável, e tudo que podemos fazer é saber que nosso julgamento é irrelevante aos olhos de Sua grandeza. Os grupos protestantes percorrerão caminhos distintos para fundamentar o valor ascético das práticas terrenas; o que os une é o fato de desautorizarem, todos eles, os estamentos e as figuras de autoridade perante Deus, abolindo essa mediação estanque entre Deus e a Terra que a hierarquia católica apresentava - talvez justamente por isso as compreensões da natureza da mediação serão tão numerosas e distintas entre os protestantes: tendo protestado contra a ortodoxia e a iconofilia, o saber sobre as origens e os "interiores" fica certamente mais nebuloso ${ }^{25}$.

A apresentação que estou propondo aqui se baseia em uma "subversão de autoridade" sediada em Calvino (e sei que a história é sempre mais complexa do que as compreensões esquemáticas que dela fazemos): Calvino aparece como a figura de autoridade que põe a autoridade estabelecida sob suspeita, e é nessa "cena primordial" que se funda o funcionamento da ética protestante conforme apresentada por Weber.

Queria, eu também, propor uma discussão baseada em uma "cena primordial”. A imagem sobre a qual proponho esse trabalho é a seguinte:

Um dia, voltando da igreja para casa com seu pai, o jovem Donald Winnicott perguntou a seu pai algumas coisas sobre religião. Frederick Winnicott respondeu: "escute, filho: leia a Bíblia, o que você encontrar lá, e decida para você mesmo o que você quer, sabe? É livre. Você não tem que acreditar no que eu penso. Forme suas próprias opiniões a respeito; apenas leia a Bíblia”. (KAHR, 1996, p. 9)

25 Remeto o leitor ao livro de Weber para aprofundamento do argumento e mesmo para avaliar a pertinência da aproximação que sugiro aqui. 
Gostaria de sugerir ao leitor que tratasse esse relato como o relato de um sonho. Parece-me que essa cena condensa, em alguma medida, os elementos envolvidos na influência e na autorização em torno da imagem-autor de Winnicott que estivemos desenvolvendo até aqui. Como todo sonho, a uma mirada distanciada ele certamente parecerá arbitrário demais, conciso demais para organizar tanto material, impressão que ao menos em minha experiência - fica para trás à medida que o sonho pode ser compartilhado e experimentado em termos do tipo de experiência que suscita e organiza. Em nosso contexto, esse "sonho" propõe mais um efeito organizador do que se passou até aqui do que a proposição de novos temas; desenvolvo a seguir, apesar disso, uma ou outra discussão que esse material me sugere ou evoca.

A cena é bastante simples; seria uma cena corriqueira, talvez até inconsequente, não fosse por Winnicott ter sido uma figura de liderança no grupo que se convencionou chamar Tradição Independente; não fosse por Winnicott quase nunca citar Freud; não fosse seu pai ter sido pastor protestante, e uma figura importante em sua cidade, e ausente no lar; não fosse a reiteração incansável por Donald, já adulto, de que era iconoclasta e claustrófobo, que não queria seguidores, que gostaria que cada um usasse seus textos como pudesse e quisesse; não fosse sua "falha de temperamento" que fazia omitir suas fontes e apresentar suas ideias de "sua própria maneira".

O pai de Winnicott, Frederick, era pastor em uma comunidade protestante; ele mesmo era, portanto, "líder" de uma comunidade que prezava acima de tudo a independência de pensamento e a forma por meio da qual cada um atinge a própria verdade sagrada. Quando responde ao filho indicando que procure a verdade em sua própria leitura da Bíblia, ele está, de alguma forma, pregando - assim como Donald poderia ser considerado como alguém pregando quando diz a Harry Guntrip, que foi seu paciente, que supunha que seus leitores tinham seu Freud (sua Bíblia) lido. É razoável supor, no entanto, que o que o pequeno Donald procurava não era exatamente ilustração teológica, mas atenção e algum carinho da parte do pai sempre tão ocupado com os ofícios comunitários e profissionais; esse elemento subsidiário confere à cena, que no geral tem um colorido bastante idílico, certo tom dramático, talvez mesmo traumático.

Masud Khan disse certa vez que Winnicott era um "protestante por natureza"; creio que não exista uma natureza protestante - o máximo que pode acontecer a alguém (e que creio ter acontecido a Winnicott) é ter sido criado radicalmente protestante, radicalmente fundado na ética protestante. A raiz protestante de Winnicott se faz notar de forma mais 
acentuada em sua posição de "iconoclasta e claustrófobo" dentro da instituição psicanalítica (protestantes são certamente "iconoclastas e claustrófobos" na instituição católica), em sua valorização dos processos singulares de acesso à verdade (a Bíblia como único caminho para a iluminação), no respeito ao processo do paciente em detrimento de eventuais insights sofisticados do analista, no discurso de recusa do lugar de enunciação da verdade. O que estive chamando ao longo do texto de "revolução não-violenta" de Winnicott no contexto da psicanálise talvez possa ser compreendido, à luz dessas discussões, como uma reforma protestante no seio da Sociedade Britânica de Psicanálise, com grandes repercussões para a história da psicanálise como um todo. É fácil ver também, nesse contexto, um matiz protestante na recusa de idolatria aos "papas" da história da psicanálise como uma tendência da psicanálise contemporânea, e o consequente questionamento das "igrejas" em torno dos grandes autores: incluindo aí Melanie Klein, Lacan, Bion e o próprio Winnicott. Freud, vale notar, continua e continuará sempre como um busto de bronze inabalável no coração totêmico da psicanálise, mesmo entre estes psicanalistas contemporâneos "pós-Reforma".

Na cena, o pai de Winnicott diz a ele que ele poderia ficar à vontade para formar sua opinião, porque "é livre"; Kahr se baseia em uma entrevista cedida por Clare Winnicott a Michael Neve em 1983, e, em se tratando da transcrição de uma entrevista da esposa de Winnicott, não há muito sentido em apego excessivo a minúcias. De qualquer forma, há um aspecto muito rico nessa passagem, que é a reiteração pelo pai de Winnicott quanto à liberdade do pequeno Donald para pesquisar e pensar como quisesse, porque it's free: é livre... e é grátis. Acho importante frisar que Winnicott parecia querer que o pai desse uma resposta, não pela resposta em si, mas pela atenção, e pelo carinho, e por ter um pai que é uma figura admirável, uma referência, alguém que fala a ele com interesse no que diz. A cena remete a isso, e creio que é um elemento decisivo, porque instala um contorno importante no personagem-autor-Donald conforme aparece na cena: temos alguém que quer uma referência, quer um pai, dirige-se a esse desejo e encontra um convite à liberdade de pensamento e ao direito de ter as próprias ideias. Se pensarmos na relação de Winnicott com a autenticidade nesse contexto, podemos supor que ele investe a liberdade de pensamento e a criatividade do sujeito quase como o autor em Bloom ou em Britton investe o predecessor (o Pai poético, nos termos de Bloom); a liberdade em Winnicott ocupa o lugar de autoridade - a pessoa tem que formar suas próprias opiniões a respeito das coisas. 
Voltemos a Weber. O papel que ele atribui ao protestantismo consiste na desvinculação da salvação a processos purgativos sacramentais - não haveria um caminho predeterminado para a salvação da alma e para a remissão dos pecados, e o fiel da balança seria pura e simplesmente o desígnio divino, que é imperscrutável olhando "do lado de cá"; a cena que isso monta no contexto religioso é o desinvestimento dos rituais de autoridade estabelecidos - desde a autoridade papal até os sacramentos e o culto às imagens sagradas - em benefício do investimento na certeza íntima da graça, que em princípio não encontra confirmações ou reforços 'internos' (vindos “de Deus”) ou 'externos' (vindos da própria vida terrena ou dos confrades e pastores). Acredito que seja relativamente fácil perceber os paralelos que estou sugerindo entre o papel da "cena primordial" em que Weber situa Calvino e a "cena primordial" em que estou situando Winnicott.

Não gostaria, no entanto, de passar a impressão de que entendo Winnicott como um "grande revolucionário" ou como um "divisor de águas" na história da psicanálise - se essa impressão é favorecida em algumas passagens do trabalho (e eu mesmo as reconheço por vezes), creio que isso se deve principalmente ao enfoque no objeto que é necessário a qualquer trabalho com circunscrição e propósito. Winnicott é obviamente um divisor de águas na história da psicanálise conforme entendida a partir das influências de sua obra - o foco do trabalho é na relevância dele, e por isso a relevância dele é maximizada, porque é dela que se trata. Recorrendo mais uma vez à clareza metodológica de Weber:

Juízos sobre a essencialidade de um fenômeno histórico, ou são juízos de valor, ou são juízos de fé - notadamente quando se tem em mente aquilo que nele por si só "tem interesse" ou que por si só "tem valor" duradouro. Ou quando se tem em mente sua significação causal em virtude de sua influência sobre outros processos: trata-se então de juízos de imputação histórica. (WEBER, [1904-1905] 2004, p. 90)

A suposta primazia do papel de Winnicott para a história posterior da psicanálise neste trabalho se deve, no meu entendimento, a um ruído necessário produzido pela própria natureza do trabalho. Winnicott certamente mudou o panorama da psicanálise, e certamente foi um dos muitos divisores de águas nessa disciplina tão centrada na genialidade dos autores individuais - acho importante, no entanto, que os estudos focados em cada um deles não inflacionem além do necessário a grandeza daquele autor. Se a história da psicanálise ocupasse uma sala de museu, os bustos de bronze seriam muitos: enquanto cada historiador da psicanálise quiser que o autor que é seu objeto privilegiado de 
estudo ocupe um lugar central, a história da psicanálise certamente será campo de muita discórdia e pouco debate pertinente. Optei por enfatizar, ao longo do trabalho, um ponto específico relacionado à autoria e à influência em Winnicott: a centralidade do paradoxo nesse aspecto de seu pensamento, de forma que a autoridade continua central e operante na configuração da obra e do campo de influências, mas operando em outros campos que não na superfície "terrena" (a tinta no papel) da obra. A relação, que inicialmente pode parecer inconsistente, de Winnicott com o reconhecimento da autoridade e da dívida entre pares, e sua postura "desobediente" em relação à autoridade estabelecida parecem encontrar sua organização mais estável no tipo de relação de autoridade que o protestantismo construiu para si. Ainda outra vez: como não estou pensando na pessoa que um dia foi Donald Winnicott, não considero que isso o "culpe" ou "desculpe" por nada; trata-se apenas da tentativa de organização de uma imagem de autor na confluência dos jogos de dívida e graça, de influência e de autorização.

Nas considerações finais de seu trabalho, Weber afirma: "não cabe evidentemente a intenção de substituir uma interpretação causal unilateralmente 'materialista' da cultura e da história por uma outra espiritualista, também ela unilateral” (WEBER, [1904-1905] 2004, p. 167). Acho que seu "interlocutor" aí é o trabalho de Marx - "unilateralmente materialista" na apresentação do "espírito do capitalismo". Acredito que aqui seria pertinente discutir uma problemática similar, e nosso interlocutor seria Harold Bloom e toda a discussão "unilateralmente" focada na angústia de influência e em sua "metapsicologia" subjacente. Tentando fazer justiça aos trabalhos do autor com que estivemos lidando, optei por não estabilizar uma dicotomia onde a leitura "paternalista" de Harold Bloom se opusesse termo a termo à leitura focada na "ascendência da ética religiosa" que, ainda que sem citar a fonte, surgiu em mim a partir da leitura proposta por Derrida para a "ética" (acredito que ele rejeitaria o termo) freudiana em termos da penetração do judaísmo do pai e da "passagem" do judaísmo do pai ao fillho ${ }^{26}$.

Há um último aspecto que eu gostaria de ressaltar em relação a essa problemática, à qual já fiz menção antes: o trabalho de Winnicott muda o estatuto aparente do pai no desenvolvimento emocional, mas isso não muda seu estatuto formativo; se o pai deixa de ser a pedra de tropeço do pensamento sobre o sujeito, o próprio enquadramento que dá as

26 A referência é ao livro Mal de arquivo: uma impressão freudiana (2001), em que Derrida faz menção à dedicatória que o pai de Freud escreve para o filho na Bíblia que deu a ele, na ocasião de seu trigésimo quinto aniversário em 1891. Retornaremos a essa cena apresentada por Derrida no próximo subcapítulo. 
condições de possibilidade para a emergência de uma busca por autenticidade continua amplamente dependente do pai. Esse deslocamento aparece na própria cena: Donald se dirige a um pai em busca de respostas, e essa remissão continua operante - o que acontece é que o pai, de seu lugar de autoridade, autoriza e incentiva o filho a buscar uma verdade que será sua, porque estará resguardada pela observância emoldurante do pai. O próprio Winnicott (o filho, o psicanalista) virá a ocupar esse lugar depois em sua posição de autoridade na psicanálise - quando, por exemplo, tornar-se uma figura de liderança na Tradição Independente.

\section{O FILHO TARDIO}

Ao final de sua vida, Winnicott mudou sua postura em relação a esse aspecto. Se lermos a apresentação a seu último livro publicado em vida, $O$ brincar e a realidade, veremos ali um autor convicto de uma contribuição singular, afirmativa e sua ao campo, que deveria ser perseguida e aprofundada por outros pesquisadores.

Calhou que eu viesse a ser um psicanalista que, talvez por ter sido pediatra, tenha percebido a importância desse universal nas vidas de infantes e crianças, e que tenha desejado integrar essa observação com a teoria que estamos a todo momento desenvolvendo (WINNICOTT, [1968] 2010, p. xvi).

Ele já vinha se aproximando há alguns anos dessa posição. Robert Rodman, por exemplo, dando conta da forma como as cartas de Winnicott estavam arquivadas, conta que desde 1951 Winnicott havia optado por arquivar uma cópia de cada carta que escrevia, tendo em vista o eventual interesse da posteridade nesses pequenos arquivos de sua vida intelectual. Rodman diz: "talvez neste ponto [1951] ele tenha começado a perceber que algum dia um registro mais completo de sua correspondência poderia vir a ter interesse, para ele pelo menos, e possivelmente para outros" (RODMAN in WINNICOTT, 2005, p. $\mathrm{x})$.

Winnicott disse em sua autobiografia que era muito difícil para ele morrer sem ter deixado um filho que pudesse matá-lo em vida e sobreviver a ele, para que algo dele pudesse sobreviver em alguém e fornecer a única continuidade que os homens conhecem (WINNICOTT, C. [1989], 1994, p. 3); mesmo que tardiamente, no entanto, ele pôde assumir a paternidade de sua obra, a singularidade de seu legado e a importância de sua 
contribuição, e me parece inegável que ele conheceu uma notável - e paradoxal, como não poderia deixar de ser - continuidade.

São notáveis, no entanto, a demora e a aparente relutância de Winnicott em aceitar ter sido, ele mesmo, representante de alguma forma de ortodoxia (ele indicou, no fim das contas, um caminho correto, uma doxa - mesmo que essa doxa fosse fundada em paradoxo, o que só depõe a favor da nossa imagem do "siga o mestre" citada antes).

O estatuto que essa doxa assume no legado winnicottiano, mesmo assim, mantém suas peculiaridades, e por uma série de motivos: um que podemos considerar retórico, um que podemos considerar político e um terceiro que podemos considerar ético.

O que chamamos retórico, o mais aparente dentre eles, deriva da postura de Winnicott, que critica e recusa na maior parte de sua vida a posição de líder, com o que a própria marcação da doxa winnicottiana como território se torna foco de uma polêmica tratamos disso em alguns pontos do trabalho. A partir daí podemos entender as particularidades das transferências a Winnicott, bastante distintas entre si e plurívocas justamente no ponto em que se considera que as leituras de Winnicott são tão numerosas e distintas entre si quanto o são os leitores, e as tão agudas diferenças regionais.

$\mathrm{Na}$ dimensão política, salientamos no item anterior (A fábula do autor) os contornos da "ética protestante" da relação de Winnicott com a instituição (no sentido de "pôr-se em pé", baseado na etimologia, e no sentido de "monopólio de objeto", como apresentada pela psicologia institucional) do saber, bem marcada pelo mito da transmissão do pai que nos chega através do relato de Clare Winnicott (a "fala" do pai que citamos acima). No contexto da instituição psicanalítica, essa "ética" ${ }^{27}$ winnicottiana teve um papel central, já que a normalização da formação e a rigidez das transferências e dos jogos de poder instituídos, à época, configuravam um impasse e um desserviço ao pensamento psicanalítico - a subversão do modelo "temente a Deus" mais clássico por Winnicott parece ter permitido, de alguma forma, a revitalização dos processos de pensamento criativo entre os membros e da própria instituição em um sentido mais amplo.

A forma como Winnicott lida com o saber psicanalítico e os dogmas em psicanálise diverge em muito do que era praxe até então ${ }^{28}$; se observarmos os relatos de Phyllis

27 Estou usando aspas nos termos ética e ética protestante porque não creio que essas noções possam ser usadas como conceitos - são apenas organizadores da discussão sustentada até aqui, mas não creio que possamos afirmar que Winnicott funde e se funde, ao fim e ao cabo, em uma ética protestante.

28 Vale ressaltar, por outro lado, que seria apressado considerá-lo um "homem à frente de seu tempo" nesse aspecto - na mesma época, Lacan, do outro lado da Mancha, e Bion já punham em novos termos a relação do psicanalista com a ortodoxia; Fairbairn, por sua vez, questionava abertamente a prioridade de 
Grosskurth (1992) a respeito da relação de Freud com a psicanálise - sua criação, sua cria - podemos perceber que, em seu nascedouro, a psicanálise era regida por uma ética diferente no que concerne ao lugar do Saber/Pai. Freud não parecia ter muito pudor em relação ao fato de assumir (para os outros e para si) o lugar de pai da horda - preocupavase, isso sim, com o futuro da psicanálise depois de sua morte, com os continuadores.

Em uma conferência em 1994, quando a casa em que Freud morreu em Londres foi transformada em Museu Freud, Derrida fez uso de um pequeno arquivo, uma dedicatória do pai de Freud a este. Acredito que, posta no lugar de "fábula do autor", a passagem seja esclarecedora do tipo de peculiaridade que tenho em mente. Consideremos, antes de mais nada, que a mensagem vem em hebraico, na folha de rosto da Bíblia - assim, na inscrição mesma da mensagem, temos uma primeira diferença radical: Winnicott lembra das palavras do pai, ditas informalmente na volta da igreja, e estas nos chegam através da esposa, ao passo que as palavras do pai de Freud vêm inscritas em hebraico no próprio livro sagrado. Acredito que já aí temos acesso a uma primeira dimensão da diferença: a mensagem em Freud é inscrita, o pai instaura seu lugar na dedicatória, no acesso ao livro sagrado, enquanto o pai de Winnicott evade-se ao lugar de autoridade com uma espécie de jogo de corpo, deixando como lugar do pai o convite à construção implicada de uma verdade própria.

A própria mensagem, a "cena" que a dedicatória monta, permite ver o aprofundamento dessa diferença:

Filho que me é querido, Shelomoh. No sétimo ano dos dias de tua vida, o Espírito do Senhor começou a te agitar e Ele se dirigiu a ti: Vai, lê no meu livro, este que eu escrevo, e se abrirão para ti as fontes da inteligência, do saber e da sabedoria. Este é o livro dos livros onde os sábios mergulharam, onde os legisladores aprenderam o saber e o direito. Tu tiveste uma visão do Todo-Poderoso, tu escutaste e te esforçaste para fazer e voaste nas asas do Espírito. Desde então, o Livro ficou reservado, como os restos das mesas, numa arca a meus cuidados. Nesse dia, onde teus anos chegaram a cinco mais trinta, eu o recobri de uma nova capa e o chamei 'jorrai, ó poços, cantai-o!' e dediquei-o a ti para que seja para ti um memorial, um lembrete da afeição de teu pai que te ama com um amor eterno. (DERRIDA, 2001 [1994], p. 36)

Como se vê, a dedicatória e o próprio livro são a marca de um retorno: o presente é a mesma Bíblia que Freud recebera quando completara sete anos, à qual seu pai incorporara uma nova capa e a dedicatória. O pai, com seu gesto, inscreve-se e designa o 
lugar de seu filho, segundo no acesso a um livro que é testamento e memória da ancestralidade (e do pai).

A dedicatória data de 6 de maio de 1891. Em 23 de outubro de 1896, o pai de Freud viria a falecer; a morte do pai seria o motor movendo a autoanálise que funda a psicanálise. A partir de 1900, com a publicação d'A interpretação dos sonhos, Freud teria sua própria bíblia, dedicatória colossal a todos seus filhos e seguidores ${ }^{29}$.

Mas retomemos a peculiaridade do lugar de Winnicott em relação à doxa psicanalítica - encaminhando-nos à terceira dimensão que, como disse, parece-me de caráter ético. Uma dimensão menos aparente da peculiaridade do lugar de Winnicott, mas que me parece primordial e fundadora, reside no pressuposto a que chegamos (se me permitem o paradoxo de um pressuposto a que se chega, e não do qual se parte) de que os processos de autorização e a constelação das angústias de influência são processos absolutamente singulares. Ronald Britton, em seu Ansiedade de publicação, fala de ansiedades e de um processo de autorização que iluminam o campo, mas que seguem sendo inexoravelmente dele. Harold Bloom se propõe a instalar um campo estável para a comparação de poetas, que seria justamente a forma como cada um constela as influências sob as quais se inscreve e como lida com as angústias decorrentes - e se seu trabalho é fundamental na instalação do campo, certamente é insuficiente para a compreensão da angústia de influência em qualquer autor, poeta ou não. As angústias de influência de Winnicott e a forma como ele se autoriza em vista do campo em que pleiteia inscrição (e onde certamente se inscreve como autor forte) são peculiares acima de tudo porque não poderiam deixar de sê-lo. Se há um ponto que valoriza esse aspecto ainda mais, este reside no fato de que a relação de Winnicott com o que supomos ser suas angústias de autorização cumprem um papel preponderante no delineamento mesmo de sua contribuição teórica ao campo $^{30}$.

\footnotetext{
29 Esse ponto é abordado magistralmente por John Forrester no capítulo Dream Readers de seu livro Dispatches from the Freud wars e em seu comentário a Interpretação dos sonhos (FORRESTER, 2009; FORRESTER, 1997, p. 138-183). O parágrafo convoca uma discussão que escapa ao propósito desse texto, mas que espero que seja empreendida posteriormente em outro lugar, por mim mesmo ou por quem quer que seja - uma espécie de "fábula do autor" de Freud, tendo a dedicatória citada como cena fundadora e Interpretação dos sonhos como uma espécie de repetição.

30 Digo isso porque suponho que haja autores que se conformam com sua posição e com o fato de serem posteriores e terem sombras menores do que seus antecessores, em relação aos quais um estudo fundado na autorização como o fiz em relação ao Winnicott seria de pouco ou nenhum valor, desmerecendo e "humilhando" o autor mais do que o entendendo. Bloom faz menção a isso em seu trabalho, caracterizando os "conformados" como poetas fracos - eu, particularmente, não vejo sentido em moralizar a discussão dessa forma.
} 


\section{CONSIDERAÇÕES FINAIS}




\title{
O LEITOR QUE FECHA O LIVRO
}

Masud Khan conta que certo dia foi procurar Winnicott, empolgado com um livro que queria sugerir que ele lesse (Freud and the crisis of our culture, de Lionel Trilling), ao que Winnicott respondeu:

\begin{abstract}
"Não adianta, Masud, me pedir para ler qualquer coisa! Se me cansar eu caio no sono no meio da primeira página, e se me interessar eu vou começar a reescrevê-la no fim daquela [mesma] primeira página”. Claro que ele estava tirando sarro dele mesmo, e de mim mais ainda, e ele de fato tinha talento nisso. Mas ele também estava falando a verdade, e a verdade entre nós, humanos, acontece apenas através de metáfora ou paradoxo (KHAN apud NEWMAN, 1995, p. 456).
\end{abstract}

Winnicott era claramente um homem muito inventivo; ao mesmo tempo, essa inventividade parecia assumir certo tom angustioso, quase como se ele não pudesse se submeter ou depender, como se a cada momento seus pensamentos tivessem de ser radicalmente seus. Essa imagem coincide com a imagem do Winnicott que escolheu cursar medicina para nunca mais depender de um médico, quando quebrou a clavícula na adolescência (KAHR, 1996; PHILLIPS, [1988] 2007; RODMAN, 2003); coincide com o Winnicott que dormia nas palestras (GOLDMAN, 1993b; CLANCIER e KALMANOVITCH, [1984] 1987); com o Winnicott quase indiferente ao "mundo lá fora" quando envolto em pensamentos (GOLDMAN, 1993b). Coincide sobremaneira com a compreensão winnicottiana de que a intelectualidade pode funcionar como uma defesa, e com o Winnicott que tinha uma repulsa pessoal pelo intelectualismo erudito (RODMAN, 2003).

Essa inventividade levada às últimas consequências parece ter uma dimensão defensiva; revela, ao mesmo tempo, a singularidade de um pensador capaz de habitar sua própria condição e retirar desta contribuições significativas para um campo de pensamento compartilhado. Mesmo que tenha dificultado as coisas para os psicanalistas em função de sua impossibilidade de pegar emprestado ou simplesmente fazer referência às ideias de outros autores, Winnicott pôde contribuir de forma decisiva para o pensamento psicanalítico compartilhado - e me parece que a denominada psicanálise trans-escolas ou a filiação à psicanálise em transferência nômade é profundamente dependente do tipo de lógica que Winnicott propõe. A impressão que se tem, retrospectivamente, é de que 
Winnicott adiciona um tom de $\operatorname{Escher}^{31}$ ao edifício metapsicológico da psicanálise, permitindo que se transite entre autorias e formas de compreensão que seriam incomunicáveis não fosse a incorporação por Winnicott da lógica do paradoxo à psicanálise. E aí acredito que a dimensão defensiva do estilo winnicottiano levou-o a criar um novo mundo para morar: o mesmo Winnicott que tinha dificuldade para se deter no texto freudiano, que recusava o formalismo, que não conseguia fazer referências explícitas às influências em seu pensamento favoreceu a criação de uma forma de circulação em psicanálise em que as filiações perdem sua ascendência autoritária, em que as separações entre os edifícios metapsicológicos são desconstruídas com uma pitada de paradoxalidade e surrealismo.

Em A angústia de influência, Harold Bloom ([1973] 2002, p. 25) afirma que “chegar atrasado, em termos culturais, jamais é aceitável para um grande escritor, embora Borges fizesse carreira explorando sua secundariedade". Podemos compreender a colocação de Bloom como uma referência aos textos de Borges sobre autores que o precederam - suas conferências sobre autores ingleses, seus prólogos e comentários. A parte que me parece mais significativa da obra de Borges, e certamente a parte que o imortalizou na literatura ocidental moderna, não passa por aí: seus trabalhos efetivamente imortais são seus contos, e neles, segundo me consta, a afirmação de Bloom é igualmente precisa, mas por outros motivos. Se em seus contos Borges explora sua secundariedade - e me parece efetivamente que o faz -, ele a explora de forma muito similar à forma como Winnicott "explora" a tradição psicanalítica: quando ele faz referências diretas à tradição, elas no geral são diagonais ou obscuras; muitas vezes, são inventadas ou desencaminhadoras. A grande diferença entre a relação de Borges e de Winnicott com a influência talvez seja que Borges tinha orgulho e prazer em ser um erudito, e conciliava sua erudição com seu trabalho de criação; a tradição conforme retratada por Borges, no entanto, assemelha-se a uma construção escheriana tanto quanto a metapsicologia a partir de Winnicott ${ }^{32}$. Se em Winnicott as inovações estão obscurecidas e os paradoxos devem ser tolerados e não resolvidos em todas as suas dimensões, em Borges, as construções mais

\footnotetext{
31 M. C. Escher (1898-1972) foi um pintor cujas obras mais famosas se assentam na ambiguidade, no paradoxo e na ilusão.

Tomando a influência do ponto de vista do "conjunto de mecanismos em última análise de natureza defensiva", o caso de Winnicott parece ser mais grave do que o de Borges, já que Borges aparentava tranquilidade em nomear influências e situar-se como retardatário. O que ambos parecem conjugar é a distorção paradoxal da influência enquanto filiação e enquanto submissão, no que chamei de "revolução nãoviolenta".
} 
notáveis da literatura erudita são fantásticas (inventadas), os autores posteriores são referência aos antecessores, as histórias se comunicam subterraneamente.

No epílogo de um de seus últimos livros, Borges afirma: "Espero que as notas apressadas que acabo de ditar não esgotem este livro e que seus sonhos continuem se ramificando na hospitaleira imaginação daqueles que agora o fecham" (BORGES, [1975] 2009).

Goldman nos leva a crer que Winnicott compartilha a expectativa que Borges declara nessa citação. Segundo ele, "Winnicott preferiria que as pessoas transformassem criativamente suas ideias, usando-as para suas próprias necessidades, a que aderissem a elas como uma nova ortodoxia" (GOLDMAN, 1993b, p. xii-xiii).

Talvez esta seja a grande convergência entre as propostas de Borges e de Winnicott: o estilo alusivo, paradoxal, escheriano convida o leitor a habitar o texto, depois de fechado o livro, para apropriar-se dele - desconstruí-lo enquanto coisa pronta, sonhá-lo a partir de seus impossíveis ângulos, criá-lo como coisa própria. As notas apressadas são só o começo; o autor convida o leitor, após o fim do livro e tendo-o já fechado, a ramificar os sonhos que o livro é: fechar o livro para sonhá-lo, para reescrevê-lo.

\section{PEDRA SOBRE PEDRA}

Não gostaria que este trabalho fosse considerado como um trabalho sobre Winnicott - menos ainda um trabalho winnicottiano. É claro que Winnicott é o personagem central e o objeto das atenções principais ao longo do percurso; acredito, no entanto, que a questão principal deste trabalho seja a autorização em psicanálise, e a forma como as angústias de influência se delineiam em psicanálise.

Winnicott debateu-se ao longo de toda sua vida com as idolatrias e idealizações, afirmou ser um iconoclasta e um claustrófobo, e declarou repetidamente que não gostaria de ser mestre de uma escola. É curioso que, ao fim e ao cabo, ele tenha emergido como uma figura de verdade no campo psicanalítico e aberto o caminho para tantos trabalhos winnicottianos ou winnicottianamente inspirados. Digo curioso porque podemos compreender sem questionar que um autor com desejo de influência assuma um lugar de influência, mas certamente temos oportunidade para um questionamento posterior quando vemos um autor que tenta evadir-se ao lugar de influência assumir esse mesmo lugar, e com penetração quase proporcional à sua ojeriza (expressa) à tal influência. 
É claro que todo autor quer que suas ideias exerçam influência - se não quisesse, não escreveria. $O$ ponto, particularmente no caso de Winnicott, parece ser que ele queria que suas ideias fossem aproveitadas, mas não sua imagem enquanto autor das ideias; como ele mesmo "apagava" as imagens de influência de que se beneficiava, usando as ideias sem citar as fontes, ele parecia querer estimular que outros fizessem o mesmo, usando suas ideias e esquecendo que tenham um dia sido dele. Independentemente de esse ter sido efetivamente o desejo de Winnicott (que sabemos sobre os desejos dele?) ou apenas seu lugar de autor, a questão a que gostaria de me ater é que parece ser impossível, em psicanálise, evadir-se às influências autorais e a seu impacto sobre o presente.

Talvez o primeiro aspecto a chamar minha atenção para o trabalho de Winnicott alguns anos atrás tenha sido essa fulguração paradoxal de seu pensamento, aparentando simultaneamente complexidade e simplicidade, rusticidade e delicadeza de pensamento, liberdade e dogma. Quando apresento a figura de autor de Winnicott como o "mestre" na brincadeira de "siga o mestre" (como fiz no capítulo 4), quero ressaltar essa doxa curiosa que é a paradoxa: em Winnicott, o paradoxo é um caminho a ser seguido, e a forma como esse caminho se apresenta é a de um caminho sem caminho, um caminho de muitos caminhos em que se perder é a melhor forma de se encontrar.

De maneiras diferentes, muitas pessoas já disseram que Winnicott não queria ser entendido, mas queria que nos entendêssemos e entendêssemos questões que fossem nossas a partir das ideias que ele veicula. É importante ressaltar, no entanto, que as ideias que ele apresenta se oferecem enquanto fôrma a partir da qual poderíamos nos reconhecer; por mais que ele quisesse que usássemos seu pensamento para nossos próprios processos, ele certamente delineia horizontes de pensamento coerentes e condizentes com o que ele estabelece - mesmo que a despeito de si mesmo - como caminhos à verdade. Ainda que por meio de paradoxos, Winnicott conseguiu afinal instalar-se como autor no campo psicanalítico de forma contundente, e creio que ao longo do processo ele tenha aberto algumas sendas para pensarmos o estatuto da influência e da autoridade no campo psicanalítico.

Segundo Weber, haveria três formas puras de exercício de poder legítimo: o poder legal, o poder tradicional e o poder carismático (WEBER, [1922] 2005). Essas formas de poder nunca se efetivam em sua forma pura na realidade, já que as cenas sociais sempre impõem uma complexidade de relações e jogos de influência que mobilizam estratégias de dominação distintas. No contexto da psicanálise, parece-me que o tipo de poder 
preponderante, de acordo com a tipologia weberiana, é o poder carismático, no qual as características singulares de uma específica pessoa constelam para que ela seja reconhecida como ordenadora legítima daqueles sob seu poder, e tal poder é outorgado espontaneamente por eles justamente na medida em que esse carisma é atribuído à pessoa em causa. Weber chama atenção para o fato de que esse tipo de poder não se transmite no tempo e não se funda em nenhum sistema ordenador que garanta sua permanência ou efetividade - à pessoa a quem se atribui características especiais cabe proceder de forma a ver reconhecida a legitimidade do poder conferido.

Se atentarmos à forma como a psicanálise se espraiou no tempo e no espaço e ao modo como os conflitos e as disputas de poder se compuseram e dispuseram, acredito que teremos mostras de que esse parece ser, de fato, o tipo de poder preponderante a legislar sobre as relações em psicanálise. Tal percepção, no entanto, conclama duas discussões que gostaria de apresentar: a primeira diz respeito à torção do lugar de autoridade na psicanálise e a segunda à permanência no tempo e à impermanência na forma da figura carismática de autoridade.

Há uma torção na psicanálise, sustentada no tempo, do processo de influência e do processo de autoridade carismáticos em relação à sua apresentação mais clássica: aquele que exerce influência o faz porque se expôs suficientemente e expôs suas intimidades. Considero clássico atribuir ao líder carismático qualidades como força, integridade, confiança e por aí vai; na psicanálise, ocorre de os atributos do líder serem retorcidos, tornando indistinguíveis o dentro e o fora: o íntegro e o distorcido, o forte e o fraco. Lembremos, a princípio, Interpretação dos sonhos (FREUD, [1900] 1973a): a psicanálise se funda em um trabalho de análise pessoal ao cabo do qual o analisado afirma ter descoberto o método para compreender as motivações inconscientes - não as dele, mas as de quem quer que se submeta ao método. Essa montagem tensa dos jogos de poder será mantida e aprofundada em vilosidades sucessivas ao longo da história da psicanálise até os dias de hoje, e me parece que o fato de a autoria de Winnicott fundar-se sobre um jogo de "sigam-me se forem capazes" (posto que ele foge daqueles que o seguem e "tenta" não ser seguido) é mais uma apresentação dessa mesma ampla problemática. Poderíamos encontrar inúmeros outros momentos dessa torção da influência e da autoridade - cito como exemplos a acusação labiríntica feita por Ferenczi de que Freud não teria analisado a transferência negativa do primeiro ao último como forma de resistência à influência, e a afirmação de Winnicott de que "a resposta a muitos problemas obscuros da prática 
psicanalítica reside no avanço da análise do analista" (WINNICOTT, [1947] 2000b, p. 279). Winnicott é um líder carismático, e o fato de convidar seus seguidores a não fazê-lo dá muito mais mostras de como seu pensamento paradoxal se estrutura do que de como a posteridade deveria agir, ou age. Se Weber, em seu trabalho, tem em vista líderes carismáticos em ordenações sociológicas mais "regulares", no caso da psicanálise, é necessário levar em conta as torções impostas aos regimes do poder e do discurso que ela implementa em sua ordenação mais íntima e radical. Parece-me importante, nesse contexto, chamar a atenção para o mérito de propostas como a transferência nômade em psicanálise e a proposta de uma psicanálise trans-escolas no sentido de, no mínimo, pulverizar as transferências. Considero razoável e maduro supor que as transferências não se "dissolverão" jamais, e nem é disso que se trata, mas certamente sairemos fortalecidos se pudermos atribuir poder carismático e prestar reverência a figuras múltiplas. Até porque, se considerarmos que o carisma é a atribuição de um dom ou graça associado a uma figura, a "reverência" a uma figura única nos deixa certamente em condição de dependência afetiva e rarefação de pensamento, justamente porque aquela figura "tampa" o espaço de inovação, só nos restando (quando muito) repetir. Repito, portanto, o desafio já muitas vezes lançado àqueles envolvidos com a psicanálise (dentre eles, Foucault e Derrida): é incontornável que se possa pensar e repensar sua história, e - mais importante - repensar a relação que estabelece com a própria história ${ }^{33}$.

Como disse, creio que há uma segunda questão a ser desdobrada a partir da sugestão de que o poder carismático predomina na gestão do poder e da influência em psicanálise, que defini como permanência no tempo e impermanência na forma das figuras de influência. Quis me referir com isso ao fato de que os autores a que se confere poder dentro do discurso psicanalítico permanecem no tempo, mesmo décadas depois de mortos (Ferenczi, Freud, Klein, Lacan, Winnicott...); temos aí uma diferença fundamental em relação às problematizações propostas por Weber, já que ele tinha em vista o exercício de poder legítimo de um homem sobre outros homens - pois bem, esses a que me refiro e tantos outros não mais são homens, posto que morreram. Essa característica fundamental aproxima o poder carismático que regularia a psicanálise ao poder legal que, ainda segundo

33 Faço menção aqui às defesas incondicionais de um ou de outro personagem da história da psicanálise, redundando muitas vezes na ocultação e na manipulação de documentos e textos centrais na psicanálise; faço menção também às defesas de uma ou de outra figura que, para o bem da comunidade, ocultam ou fecham os olhos a outros pensamentos e autores. Remeto o leitor interessado nessa discussão à dissertação de mestrado de Rafael Alves Lima, "A categoria de poder na clínica psicanalítica: entre Michel Foucault e Jacques Lacan" (LIMA, 2012). 
Weber, é aquele poder regulado por textos e normas que estabelecem princípios de regulação, e aos homens "no poder" caberia o papel de fazer cumprir o poder que está previsto, conforme está previsto. Pois bem, consideremos que Winnicott e Freud e Lacan não são homens posto que morreram; poderíamos então supor que seus textos são como "textos ordenadores", e que os psicanalistas "influentes" de atualmente (esses, sim, homens e influentes) simplesmente "despacham" o cotidiano cumprindo normas e dizendo: "sua ideia está correta, porque está de acordo com Freud" ou "não, isso não é correto porque Winnicott não previu assim", e leríamos aí correlatos perfeitos de burocratas a dizer se podemos ou não pisar na grama ou circular pelas ruas naquele determinado horário.

O ponto é que com alguma atenção percebemos que não é assim que a história procede: afinal temos psicanalistas ilustres com obras estabelecidas nos anos 1920, nos anos 1930, nos anos 1950, 1960... e todas essas obras se fundam em alguma medida no velho método freudiano estabelecido em $1900 \mathrm{com}$ a Interpretação. De alguma forma ainda estamos, e é provável que estejamos sempre, tentando compreender tudo o que está implicado naquele tantinho de trabalho que Freud tinha diante de seu nariz, e sobre esse tantinho nos debruçamos como Alice a cair no buraco da árvore. Como bem o disse Foucault, estamos diante de uma hermenêutica da suspeita a desdobrar-se infinita sobre si mesma, apoiando-nos aqui e ali em algumas tantas figuras que nos "conduzem". Bem dizendo, creio que mobilizamos a permanência no tempo das figuras de autoridade, torcendo-as conforme podemos na busca do que nos pareça verdade, e nesse processo conduzimos o que seriam as mesmas figuras, mas que de fato não são: o Freud dos anos 1930 não é o Freud dos anos 1960, que não é o Freud dos dias de hoje. Ou seja: o poder carismático que regula as relações de poder em psicanálise diz respeito à transferência às figuras de influência e à forma como essas figuras constelam um horizonte discursivo que nos permite enunciar o que queremos dizer. Winnicott, ao suprimir as figuras carismáticas (protestante que era), construiu seu pensamento na ossatura radical da tradição e da subversão, incorporando elementos da tradição ora de forma dogmática, ora de forma subversiva, e construindo nessa malha tensa de adesão e resistência um pensamento inovador e com poder de penetração discursiva. Não acho, por outro lado, que o Freud de hoje seja "mais" ou "menos" que o Freud dos anos 1960 - acho que ele é outro. Não acho que a psicanálise esteja em busca da verdade radical ou do fim da história do inconsciente, não acho que seja possível encontrar o umbigo dos sonhos, ou o umbigo do pensamento freudiano, ou o umbigo da autoria em Winnicott. O que creio que podemos fazer é tentar 
articular com consistência e impetuosidade um pensamento que presentifique as figuras carismáticas, de forma a ler Winnicott, e Freud, e Klein, e Lacan para que "possamos pensarem" os problemas e os desafios da clínica e da vida de nosso tempo.

\section{O AUTOR QUE FECHA O LIVRO}

Passei muito tempo considerando que este trabalho seria constituído por três partes, e não por duas, como hoje está composto: além das partes relativas à "apropriação" e à "posse", haveria uma primeira, anterior, chamada "herança". A principal diferença em termos de conteúdo seria um capítulo a mais, que seria o único a compor a parte intitulada "posse". Nesse capítulo que nunca consegui escrever, haveria dois ensaios: um sobre a relação entre a discussão do trabalho e a clínica psicanalítica, e outro sobre a relação entre este mesmo trabalho e a teoria da história da psicanálise (mais precisamente, sobre o estatuto do "arquivo", observando a conceituação de Derrida).

A implicação sub-reptícia daquela divisão, que hoje me é clara, mas que ignorei por muito tempo, é que a "herança" em si seria apenas a primeira parte do processo de "tornarse si mesmo". Dessa forma, o que ficava sugerido é que a herança está lá, estática, e à medida que se consegue apropriar-se dela e torná-la posse, ela deixaria de ser herança. Embutida nessa composição do trabalho, na estrutura mesma dele, havia uma resistência à tradição, à herança e à influência, como se chegando ao fim do trabalho eu tivesse me apropriado e superado o que inicialmente era herança, fazendo com que deixasse de ser herança.

Nada mais distante da compreensão da herança conforme a entendemos do que isso. E, no entanto, tê-lo-ia feito - por pouco não o fiz. Acredito que isso não seja anormal de minha parte - acredito que me deixei cegar por um desejo que não é só meu: o desejo de superar a herança e "deixá-la para trás", estar "acima" dela. Esse é o ponto nodal da angústia de influência, manifestando-se nas minúcias do próprio trabalho. Ao fazer um estudo sobre angústia de influência, estive prestes a incutir no seio de meu trabalho resistências à herança, tentando pôr-me à parte e/ou acima dela: por um lado, "fechando a porta à herança", por meio da estruturação do trabalho; por outro, "maquiando-me de pósherdeiro", encerrando a dissertação com um capítulo alheio à argumentação em pauta, como se encerrasse o trabalho com um "show à parte".

O trabalho que ora se conclui reflete uma dissertação, fruto de uma pesquisa; mais 
que isso, no entanto, reflete uma trajetória pessoal pelos obscuros caminhos da autorização e da influência em mim. Ao longo da pesquisa, tive crises de autoria, mudanças de trajeto e experiências pessoais de insight teórico, irrupções que me davam mostra do quanto o trabalho me implicava pessoalmente.

Por isso, encerro o trabalho a despeito de uma tendência em mim, tendência de não encerrar; porque certamente não concluo com a escrita meu processo de autorização, nem "supero" minhas angústias de influência. Numa das muitas formas da minha resistência a encerrar, projetava acompanhar o leitor em uma história, uma ficção. Nessa história, do literato Nelson Bond, conta-se do encontro do protagonista, um escritor em crise criativa, com uma livraria; nessa livraria o protagonista encontra livros ambicionados, mas não escritos - livros que os autores gostariam de ter escrito, mas não conseguiram escrever. Bond desfila alguns: Agamenon de Shakespeare, Rei Arthur da Bretanha de John Milton, O Leprechaun de Donn Byrne - livros que nunca foram escritos. O conto dá notícia dessa livraria, a livraria dos livros não-escritos (BOND, 2005).

Acredito que, se fôssemos lá, encontraríamos também um exemplar de Autorização e angústia de influência em Winnicott, escrito por Wilson Franco. Na verdade não só um: vários. Encontraríamos também a autobiografia interrompida de Winnicott, Not less than everything, e talvez mesmo os livros encerrados e publicados de Winnicott (acho pouco provável que ele tenha ficado absoluta e incondicionalmente satisfeito com seus livros).

Pensei em sugerir esse passeio com o leitor - mas, pensando melhor, não acho que fosse um bom caminho: o não-escrito nos agracia com a ilusão da perfeição, mas nos tolhe o direito de pertencermos à história, a história com seus erros e acertos, com tudo o que tem a nos ensinar como legado e a nos impor como desafio.

Passemos ao largo da livraria, da sedutora livraria do que poderia-ter-sido. Creio que estaremos melhor entre os livros escritos, entre as coisas ditas, entre as influências daqueles a quem devemos tudo e em meio às limitações que definem quem somos - a dor e a delícia de sermos, sabermos ser, suportarmos ser apenas um pontinho no universo. 


\section{REFERÊNCIAS}

AB'SÁBER, Tales A. M. Winnicott, seu Freud e a psicanálise. Percurso, São Paulo, n. 19, 2. sem. 1997.

ABRAM, Jan. The language of Winnicott: a dictionary and guide to understanding his work. New Jersey: Jason Aronson, 1996.

AGAMBEN, Giorgio. (1995). Homo sacer: o poder soberano e a vida nua 1. Belo Horizonte: Editora UFMG, 2010.

ARAÚJO, Teo Weingril. Tradição e originalidade no pensamento de Donald Winnicott. Dissertação (Mestrado em Psicologia) - Instituto de Psicologia, Universidade de São Paulo, São Paulo, 2005.

BARROS, Manoel de. (1996). Livro sobre nada. In: Poesia completa. São Paulo: Leya, 2010.

BARTHES, Roland. (1973). O prazer do texto. São Paulo: Perspectiva, 2010.

BEZERRA JR., Benilton; ORTEGA, Francisco (Orgs.). Winnicott e seus interlocutores. Rio de Janeiro: Relume Dumará, 2007.

BLOOM, Harold. (1973). Angústia de influência: uma teoria da poesia. Rio de Janeiro: Imago, 2002.

BOND, Nelson. A livraria. In: TAVARES, Braulio. Contos fantásticos no labirinto de Borges. Rio de Janeiro: Casa da Palavra, 2005. . (1975). O livro de areia. São Paulo: Companhia das Letras, 2009.

BRITTON, Ronald. Ansiedade de publicação. In: Janeiro: Imago, 2003.

CASTRO, Edgardo. Vocabulário de Foucault. Belo Horizonte: Autêntica, 2009.

CLANCIER, Anne; KALMANOVITCH, Jeannine. (1984). Winnicott and paradox: from birth to creation. New York: Tavistock Publications, 1987.

DERRIDA, Jacques. (1994) Mal de arquivo: uma impressão freudiana. Rio de Janeiro: Relume Dumará, 2001.

DOSSE, François. (2005). O desafio biográfico: escrever uma vida. São Paulo: Edusp, 2009.

FIGUEIREDO, Luís Claudio. A tradição ferencziana de Winnicott: apontamentos sobre regressão e regressão terapêutica. Revista Brasileira de Psicanálise, São Paulo, v. 36, n. 4, 2002. 
As diversas faces do cuidar: novos ensaios de psicanálise contemporânea. São Paulo: Escuta, 2009.

FORRESTER, John. Dispatches from the Freud wars: psychoanalysis and its passions. Londres: Harvard University Press, 1997a.

1997b.

Truth games: lies, money, and psychoanalysis. Londres: Harvard University Press,

A interpretação dos sonhos: a caixa-preta dos desejos. Rio de Janeiro: Civilização Brasileira, 2009.

FOUCAULT, Michel. (1970). Ordem do discurso. São Paulo: Edições Loyola, 2004.

. (1969). O que é um autor? In:

Estética: literatura e pintura, música e cinema. Rio de Janeiro: Forense Universitária, 2009. (Ditos e escritos, v. III).

. (1972). História da loucura. São Paulo: Editora Perspectiva, 2004.

FREUD, Sigmund (1900). A interpretação dos sonhos. In: Obras completas de

Sigmund Freud. Madri: Biblioteca Nueva, 1973a.

. (1910). Uma recordação infantil de Leonardo da Vinci. In: . Obras completas de Sigmund Freud. Madri: Biblioteca Nueva, 1973b.

. (1937). Construções em análise. In: Obras completas de Sigmund Freud. Madri: Biblioteca Nueva, 1973c.

GOLDMAN, Dodi. Introduction. In: Winnicott. Pennsylvania: Jason Aronson, 1993a.

(Ed.). In one's bones: the clinical genius of In search of the real: the origins and originality of D. W. Winnicott. Pennsylvania: Jason Aronson, 1993b.

GRAÑA, Roberto B. Origens de Winnicott: ascendentes psicanalíticos e filosóficos de um pensamento original. São Paulo: Casa do Psicólogo, 2007.

GROSSKURTH, Phyllis. O círculo secreto: o círculo íntimo de Freud e a política da psicanálise. Rio de Janeiro: Imago, 1992.

GURFINKEL, Decio. O carretel e o cordão. Percurso, São Paulo, n. 17, 1996.

KAHR, Brett. Winnicott: a biographical portrait. Madison: International Universities Press, 1996.

KING, Pearl; STEINER, Riccardo (Orgs.). (1991). As controvérsias Freud-Klein 19411945. Rio de Janeiro: Imago, 1998.

KUPERMANN, Daniel. Transferências cruzadas: uma história da psicanálise e suas 
instituições. Rio de Janeiro: Revan, 1996.

. Presença sensível: cuidado e criação na clínica psicanalítica. Rio de Janeiro: Civilização Brasileira, 2008.

LIMA, Rafael Alves. A categoria de poder na clínica psicanalítica: entre Michel Foucault e Jacques Lacan. Dissertação (Mestrado em Psicologia) - Instituto de Psicologia, Universidade de São Paulo, São Paulo, 2012.

LOPARIC, Zeljco. Winnicott: uma psicanálise não-edipiana. Revista Percurso, São Paulo, v. 17, n. 2, 1996.

LOUREIRO, Inês. Sobre algumas disposições metodológicas de inspiração freudiana. In: QUEIROZ, Edilene Freire de; SILVA, Antonio Ricardo R. da (Orgs.). Pesquisa em psicopatologia fundamental. São Paulo: Escuta, 2002.

NEWMAN, Alexander. Non-compliance in Winnicott's words: a companion to the work of D.W.Winnicott. New York: New York University Press, 1995.

OGDEN, Thomas. (2001). Lendo Winnicott. Revista Brasileira de Psicanálise, São Paulo, v. 36, n. 4, 2002.

OUTEIRAL, José; CELERI, Eloisa Helena R. V. A tradição freudiana de Winnicott: a situação edípica (e sobre o pai?). Revista Brasileira de Psicanálise, São Paulo, v. 36, n. 4, 2002.

PHILLIPS, Adam. (1988). Winnicott. Londres: Penguin, 2007.

PONTALIS, Jean-Bertrand. (1977). Entre o sonho e a dor. Aparecida: Idéias e Letras, 2005.

RODMAN, Robert. Winnicott: life and work. Cambridge: Da Capo Press, 2003.

SEGAL, Hanna. (1955) - Uma concepção psicanalítica da estética. In: KLEIN, Melanie; HEIMANN, Paula; MONEY-KYRLE, R. E. (Orgs.). Temas de psicanálise aplicada. Rio de Janeiro: Zahar Editores, 1969

STEIN, Conrad. A paternidade da obra. In: . O psicanalista e seu ofício. São Paulo: Escuta, 1988a. Uma conferência sobre a identificação com Freud. In: O psicanalista e seu ofício. São Paulo: Escuta, 1988b.

WEBER, Max. (1904-1905). A ética protestante e o espírito do capitalismo. São Paulo: Companhia das Letras, 2004. . (1922). Os três tipos puros do poder legítimo. In: Três tipos de poder e outros escritos. Lisboa: Editora Tribuna, 2005.

WINNICOTT, Clare. D. W. W.: uma reflexão. In: WINNICOTT, Clare; SHEPHERD, Ray; 
DAVIS, Madeleine. (Orgs.). Explorações psicanalíticas. Porto Alegre: Artmed, 2007.

WINNICOTT, Donald W. (1947). Collected papers: through paediatrics to psychoanalysis. Nova Iorque: Basic Books, 1975.

. (1988). Natureza humana. Rio de Janeiro: Imago, 1990.

. (1945). Desenvolvimento emocional primitivo. In:

Da pediatria à

psicanálise. Rio de Janeiro: Imago, 2000a.

(1953). Objetos transicionais e fenômenos transicionais. In:

Da pediatria à

psicanálise. Rio de Janeiro: Imago, 2000b.

. (1947). O ódio na contratransferência. In:

Da pediatria à psicanálise. Rio

de Janeiro: Imago, 2000b.

. (1987). O gesto espontâneo. São Paulo, 2005.

. (1967). DWW sobre DWW. In: WINNICOTT, Clare; SHEPHERD, Ray; DAVIS, Madeleine (Orgs.). Explorações psicanalíticas. Porto Alegre: Artmed, 2007.

. (1968). The use of an object and relating through identifications. In: Playing and reality. Londres: Routledge Classics, 2010.

. (1968). Creativity and its origins. In:

Routledge Classics, 2010.

. Playing and reality. Londres:

ZARETSKY, Eli. Secrets of the soul: a social and cultural history of psychoanalysis. Nova York: Vintage Books, 2005. 